\title{
The Asymmetry of Western Boundary Currents in the Upper Atlantic Ocean
}

\author{
REINER ONKEN \\ Institut für Meereskunde an der Universität Kiel, Kiel, Germany
}

(Manuscript received 23 February 1993, in final form 19 August 1993)

\begin{abstract}
Observations of upper-ocean western boundary current (WBC) transports reveal asymmetries between the Northern and the Southern Hemispheres of the Atlantic Ocean. To find out what mechanism might cause these asymmetries the linearized steady-state vorticity equation is applied to the interior of a layer of constant thickness representing the upper Atlantic Ocean. WBC transports are then required to balance the interior volume flux deficit. The ocean is forced by climatological wind stress at the surface; thermohaline forcing is introduced by vertical motion at the lower boundary. A series of model runs using selected combinations of different basin geometries, wind stress fields, and thermohaline forcing patterns yields the following results: asymmetries of WBC transports cannot be explained by the topography shape of coastlines. The wind stress causes $12 \mathrm{~Sv}$ (Sv $\equiv 1 \times 10^{6} \mathrm{~m}^{3} \mathrm{~s}^{-1}$ ) cross-equatorial transport to the north but it cannotaccount for the other WBC asymmetries. These can be explained by superimposing a thermohaline flow component to the wind-driven circulation. The best agreement with observations could be obtained from a model run driven by a sinking rate of $20 \mathrm{~Sv}$ in the northern North Atlantic and $4 \mathrm{~Sv}$ in the Weddell Sea compensated by $15 \mathrm{~Sv}$ return flow from other oceans via the Agulhas Current or Drake Passage and uniform upwelling of $9 \mathrm{~Sv}$ in the Atlantic. In tropical and subtropical latitudes this run reproduces all observed asymmetries, but in subpolar latitudes the model fails.

Further conclusions can be drawn from the model results. (i) Up to $20 \mathrm{~Sv}$ northward transport of Antarctic Intermediate Water is needed at about $10^{\circ} \mathrm{S}$ to explain the difference of modeled transports and observations. For the same reasons an Antilles Current of up to $16 \mathrm{~Sv}$ is required. (ii) The major part of the northward heat transport in the North Atlantic has to occur via the tropical countercurrents and the North Equatorial Current. Only less than $7 \mathrm{~Sv}$ take the shortest way to the Caribbean via the Guyana Current. (iii) Fifty-six percent of the Florida Straits transport is wind driven.
\end{abstract}

\section{Introduction}

Using first-order concepts, the general circulation pattern of the upper Atlantic Ocean can be described by a system of basinwide gyres and zonal currents. According to Stommel (1965) continuity of mass is maintained by western boundary currents (WBCs). The equatorward Labrador Current (LC) and Malvinas Current (MC) are closing the subpolar gyres, whereas the poleward WBCs closing the subtropical gyres are the Brazil Current (BC) in the South Atlantic and the system Guyana Current, Caribbean Current, Antilles Current, Florida Current (FC), and the Gulf Stream in the Northern Hemisphere. In the following, the abbreviation NASBC (North Atlantic subtropical boundary current) will be attributed to that system. No such gyre-closing function is evident for the equator-crossing North Brazil Current (NBC).

Observations suggest that WBCs in the Atlantic are highly asymmetric about the equator with respect to their counterparts in the other hemisphere. A summary of observed transports for the Atlantic upper-ocean

Corresponding author address: Dr. Reiner Onken, Institut für Meereskunde an der Universität Kiel, Düsternbrooker Weg 20, D24105 Kiel 1, Germany.
WBCs is given in Table 1. Only those values have been included referring to boundary currents in the strict sense; that is, transport numbers for WBCs after separating from the western coast have been ignored. This is not true for the Caribbean Current, the transport of which is evaluated by meridional integration of the inflow through the passages of the Lesser Antilles. Although this table is a composite of values measured only over a short period of time and those representing long-term averages, a plot of the transport numbers versus latitude (Fig. 1) yields a rather consistent picture revealing the following major features:

- Poleward transports in the subtropical WBCs are very much stronger in the Northern Hemisphere than in the Southern Hemisphere. Maximum NASBC transports of $64 \mathrm{~Sv}\left(\mathrm{~Sv} \equiv 1 \times 10^{6} \mathrm{~m}^{3} \mathrm{~s}^{-1}\right)$ can be found near Cape Hatteras at $35^{\circ} \mathrm{N}$. In contrast, maximum poleward transports of the $\mathrm{BC}$ are $23 \mathrm{~Sv}$, found at $38^{\circ} \mathrm{S}$ and $43^{\circ} \mathrm{S}$.

- The LC seems to be very much weaker than the MC. Although Table 1 contains only three LC transport numbers, its upper-ocean transport of $\sim 5 \mathrm{~Sv}$ is confirmed by other authors (Worthington 1970; McCartney and Talley 1984) based on budget calculations and box models. The statistics for the MC numbers is 
TABLE 1. Observed Atlantic upper-ocean western boundary current transports. C: current meters, D: dynamic method (geostrophic), E: inverted echo sounders, M: diagnostic model, P: profiler, and T: transport floats or parachute drogues.

\begin{tabular}{|c|c|c|c|c|c|}
\hline Author & Method & $\begin{array}{l}\text { Reference } \\
\text { (m) }\end{array}$ & $\begin{array}{l}\text { Latitude } \\
\text { (degrees) }\end{array}$ & $\begin{array}{c}\text { Transport } \\
\text { Sv }\end{array}$ & Remarks \\
\hline Clarke (1984) & $\mathrm{D}$ & 1500 & 47 & -6 & budget estimate \\
\hline Hill et al. $(1972)^{\oplus}$ & C, D & $?$ & 47 & -6 & \\
\hline Wolford $(1966)^{\oplus}$ & $\mathrm{T}, \mathrm{D}$ & $?$ & 47 & -6 & \\
\hline Richardson and Knauss (1971) & $\mathrm{T}$ & 900 & 35 & 50 & \\
\hline Knauss (1969) & $\mathrm{T}$ & bottom & 35 & 63 & bottom $>1000 \mathrm{~m}$ \\
\hline Barrett (1965) & $\mathrm{D}$ & variable & 35 & 64 & \\
\hline Barrett (1965) & $\mathbf{D}$ & variable & 35 & 54 & \\
\hline Knauss (1969) & $\mathrm{T}$ & bottom & 34 & 57 & bottom $>1000 \mathrm{~m}$ \\
\hline Swallow and Worthington (1961) & $\mathbf{T}$ & $\approx 1800$ & 33 & 64 & \\
\hline Richardson et al. (1969) & $\mathbf{T}$ & bottom & 33 & 53 & bottom $<1000 \mathrm{~m}$ \\
\hline Knauss (1969) & $\mathrm{T}$ & bottom & 32 & 52 & bottom $>1000 \mathrm{~m}$ \\
\hline Richardson et al. (1969) & $\mathrm{T}$ & bottom & 30 & 37 & bottom $<1000 \mathrm{~m}$ \\
\hline Richardson et al. (1969) & $\mathbf{T}$ & bottom & 28 & 35 & bottom $<1000 \mathrm{~m}$ \\
\hline Richardson et al. (1969) & $\mathbf{T}$ & bottom & 27 & 33 & bottom $<1000 \mathrm{~m}$ \\
\hline Richardson et al. (1969) & $\mathrm{T}$ & bottom & 26 & 32 & bottom $<1000 \mathrm{~m}$ \\
\hline Richardson and Schmitz (1965) & $\mathrm{T}$ & bottom & 26 & 36 & bottom $<1000 \mathrm{~m}$ \\
\hline Niiler and Richardson (1973) & $\mathrm{T}$ & bottom & 26 & 30 & bottom $<1000 \mathrm{~m}$ \\
\hline Richardson et al. (1969) & $\mathrm{T}$ & bottom & 24 & 30 & bottom $<1000 \mathrm{~m}$ \\
\hline Montgomery (1941) & $\mathrm{D}$ & 1200 & 24 & 28 & \\
\hline Gordon (1967) & $\mathrm{D}$ & variable & 22 & 28 & \\
\hline Gordon (1967) & D & variable & 22 & 26 & $16^{\circ}-22^{\circ}$ \\
\hline Gordon (1967) & D & variable & 20 & 33 & $10^{\circ}-20^{\circ}$ \\
\hline Model (1950) & $\mathrm{C}$ & 230 & 20 & 28 & $13^{\circ}-20^{\circ}$ \\
\hline Model (1950) & $\mathrm{C}$ & 230 & 19 & 28 & $13^{\circ}-19^{\circ}$ \\
\hline Mazeika (1973) & D & 1200 & 18 & 29 & $11^{\circ}-18^{\circ}$ \\
\hline Model (1950) & $\mathrm{C}$ & 230 & 18 & 28 & $13^{\circ}-18^{\circ}$ \\
\hline Gordon (1967) & $\mathrm{D}$ & variable & 18 & 28 & $11^{\circ}-18^{\circ}$ \\
\hline Gordon (1967) & D & variable & 18 & 33 & $11^{\circ}-18^{\circ}$ \\
\hline Gordon (1967) & D & variable & 17 & 26 & $11^{\circ}-17^{\circ}$ \\
\hline Model (1950) & $\mathrm{C}$ & 230 & 17 & 28 & $13^{\circ}-17^{\circ}$ \\
\hline Mazeika (1973) & D & 1200 & 17 & 22 & $11^{\circ}-17^{\circ}$ \\
\hline Model (1950) & $\mathrm{C}$ & 230 & 16 & 28 & $13^{\circ}-16^{\circ}$ \\
\hline Model (1950) & C & 230 & 15 & 28 & $13^{\circ}-15^{\circ}$ \\
\hline Stalcup and Metcalf (1972) & $\mathrm{C}$ & bottom & 15 & 25 & $11^{\circ}-16^{\circ}$ \\
\hline Model (1950) & $\mathrm{C}$ & 230 & 14 & 28 & $13^{\circ}-14^{\circ}$ \\
\hline Mazeika (1973) & $\mathrm{D}$ & 1200 & 13 & 14 & $11^{\circ}-13^{\circ}$ \\
\hline Mazeika et al. (1980) & $\mathrm{D}$ & 700 & 13 & 15 & $11^{\circ}-13^{\circ}$ \\
\hline Johannessen (1968) & $\mathrm{D}$ & 1000 & 13 & 26 & $11^{\circ}-13^{\circ}$ \\
\hline Mazeika (1973) & D & 1200 & 13 & 11 & $11^{\circ}-13^{\circ}$ \\
\hline Febres-Ortega and Herrera $(1976)^{\dagger}$ & D & $?$ & 13 & 13 & $11^{\circ}-13^{\circ}$ \\
\hline Hazelworth and Starr $(1975)^{\dagger}$ & $\mathrm{D}$ & $?$ & 12 & 17 & \\
\hline Flagg et al. (1986) & $\mathrm{C}$ & 500 & 6 & 19 & \\
\hline Flagg et al. (1986) & C & 500 & 5 & 21 & \\
\hline Flagg et al. (1986) & $\mathrm{C}$ & 500 & 4 & 21 & \\
\hline Flagg et al. (1986) & $\mathrm{C}$ & 500 & 3 & 52 & \\
\hline Schott (1992, pers. comm.) & $\mathrm{C}$ & 1000 & 0 & 27 & \\
\hline Schott (1992, pers. comm.) & $\mathrm{C}$ & 1000 & -5 & 23 & \\
\hline Stramma et al. (1990) & $\mathrm{D}$ & 500 & -7 & 17 & \\
\hline Stramma et al. (1990) & $\mathrm{D}$ & 500 & -8 & 5 & \\
\hline Stramma et al. (1990) & $\mathrm{D}$ & 500 & -9 & 5 & \\
\hline Stramma et al. (1990) & D & 500 & -10 & -1 & \\
\hline Stramma et al. (1990) & $\mathrm{D}$ & 500 & -12 & -2 & \\
\hline Stramma et al. (1990) & $\mathrm{D}$ & 500 & -13 & -4 & \\
\hline Stramma et al. (1990) & D & 500 & -13 & -2 & \\
\hline Stramma et al. (1990) & D & 500 & -15 & -6 & \\
\hline Stramma et al. (1990) & $\mathrm{D}$ & 500 & -16 & -4 & \\
\hline Stramma et al. (1990) & $\mathrm{D}$ & 500 & -16 & -6 & \\
\hline Stramma et al. (1990) & $\mathrm{D}$ & 500 & -18 & -1 & \\
\hline Stramma et al. (1990) & D & 500 & -19 & -4 & \\
\hline Stramma et al, (1990) & D & 500 & -19 & -6 & \\
\hline Miranda and Castro Filho $(1982)^{\S}$ & $\mathrm{D}$ & $\approx 500$ & -19 & -7 & \\
\hline Evans et al. (1983) & $\mathrm{D}$ & 500 & -19 & -5 & \\
\hline Evans et al. (1983) & D & 500 & -20 & -4 & \\
\hline Evans et al. (1983) & D & 1000 & -20 & -7 & \\
\hline
\end{tabular}


TABLE 1. (Continued)

\begin{tabular}{|c|c|c|c|c|c|}
\hline Author & Method & $\begin{array}{l}\text { Reference } \\
\text { (m) }\end{array}$ & $\begin{array}{l}\text { Latitude } \\
\text { (degrees) }\end{array}$ & $\begin{array}{c}\text { Transport } \\
\text { Sv }\end{array}$ & Remarks \\
\hline Stramma et al. (1990) & $\mathrm{D}$ & 500 & -20 & -1 & \\
\hline Stramma et al. (1990) & $\mathrm{D}$ & 500 & -20 & -2 & \\
\hline Stramma et al. (1990) & $\mathrm{D}$ & 500 & -20 & -2 & \\
\hline Evans et al. (1983) & $\mathrm{D}$ & 500 & -22 & -4 & \\
\hline Stramma (1989) & $\mathrm{D}$ & 600 & -23 & -10 & \\
\hline Signorini (1978) & $\mathrm{D}$ & 600 & -23 & -7 & \\
\hline Signorini (1978) & $\mathrm{D}$ & 600 & -24 & -9 & \\
\hline Signorini (1978) & $\mathrm{D}$ & 600 & -24 & -8 & \\
\hline Evans et al. (1983) & $\mathrm{D}$ & 500 & -24 & -4 & \\
\hline Evans et al. (1983) & $\mathrm{D}$ & 500 & -24 & -8 & \\
\hline Evans and Signorini (1985) & $P$ & 400 & -24 & -11 & \\
\hline Stramma (1989) & $\mathrm{D}$ & 600 & -24 & -10 & \\
\hline Sverdrup et al. (1942) & $\mathrm{D}$ & $1400 ?$ & -30 & -10 & . \\
\hline Zemba (1990) & $\bar{D}$ & $?$ & -31 & -20 & \\
\hline Evans and Mascarenhas" & $\mathrm{P}$ & 800 & -31 & -17 & \\
\hline Stramma (1989) & $\mathrm{D}$ & 1600 & -32 & -19 & \\
\hline Stramma (1989) & $\mathrm{D}$ & 1600 & -33 & -12 & \\
\hline Garzoli and Bianchi (1987) & $\mathrm{E}$ & 800 & -38 & -10 & \\
\hline Garzoli and Bianchi (1987) & $\mathrm{E}$ & 800 & -38 & -23 & \\
\hline Garzoli and Garraffo (1989) & $\mathrm{D}$ & 800 & -38 & -9 & \\
\hline Garzoli and Garraffo (1989) & $\mathrm{D}$ & 800 & -38 & -6 & \\
\hline Garzoli and Garraffo (1989) & $\bar{E}$ & 800 & -38 & -12 & \\
\hline Garzoli and Garraffo (1989) & $\bar{E}$ & 800 & -38 & -11 & \\
\hline Garzoli and Garraffo (1989) & $\mathrm{E}$ & 800 & -38 & -11 & \\
\hline Gordon and Greengrove (1986) & $\mathrm{D}$ & 1400 & -38 & -19 & \\
\hline Gordon and Greengrove (1986) & $\mathrm{D}$ & 1400 & -38 & 6 & \\
\hline Gordon (1989) & $\mathrm{D}$ & 1500 & -38 & -22 & \\
\hline Schemainda (1980) & $\mathrm{D}$ & 800 & -42 & -18 & \\
\hline Schemainda (1980) & $\mathrm{D}$ & 800 & -42 & -20 & \\
\hline Gordon and Greengrove (1986) & $\mathrm{D}$ & 1400 & -42 & -20 & \\
\hline Gordon and Greengrove (1986) & $\mathrm{D}$ & 1400 & -42 & 10 & \\
\hline Piola and Bianchi (1990) & $\mathrm{D}$ & $1000 ?$ & -42 & 12 & \\
\hline Gordon (1989) & $\mathrm{D}$ & 1500 & -43 & -23 & \\
\hline Zyryanov and Severov (1979) & $\mathbf{M}$ & 6030 & -45 & 32 & \\
\hline Zyryanov and Severov (1979) & $\mathbf{M}$ & 6030 & -45 & 40 & \\
\hline Gordon and Greengrove (1986) & $\mathrm{D}$ & 1400 & -46 & 11 & \\
\hline
\end{tabular}

- Cited by Clarke (1984).

${ }^{\S}$ Cited by Peterson and Stramma (1991).

† Cited by Mazeika et al. (1980).

${ }^{*}$ Cited by Gordon (1989).

also rather poor, but from the total of six values, five are significantly larger than the corresponding LC numbers.

- In the Southern Hemisphere there is an equatorward WBC between $\sim 10^{\circ} \mathrm{S}$ and the equator. No such transport can be found in the other hemisphere in the corresponding latitude range, where the WBC is directed poleward. Hence, the equatorial region is characterized by northward WBC transport due to the NBC, which has a peak transport of $27 \mathrm{~Sv}$ on the equator, if the $52 \mathrm{~Sv}$ at $3^{\circ} \mathrm{N}$ reported by Flagg et al. (1986) are considered as an outlier.

- Except in the LC region, there is poleward WBC transport everywhere in the Northern Hemisphere. In addition to the transport maxima at the equator and at $35^{\circ} \mathrm{N}$, a well-established minimum of $\sim 11 \mathrm{~Sv}$ can be found at $13^{\circ} \mathrm{N}$.
One might think of at least three possible physical causes creating these asymmetries:

- interhemispheric asymmetries of the wind stress pattern,

- the topography shape of the coastal and shelf boundaries, and

- the thermohaline circulation.

Information on what mechanism might be the dominant one can only be gained from model studies because there is no way to separate observed transports into contributions due to either of these three mechanisms.

To determine whether differences of wind stress patterns in the North and South Atlantic might lead to WBC asymmetries, results of purely wind-driven models forced by realistic winds and extending over both 


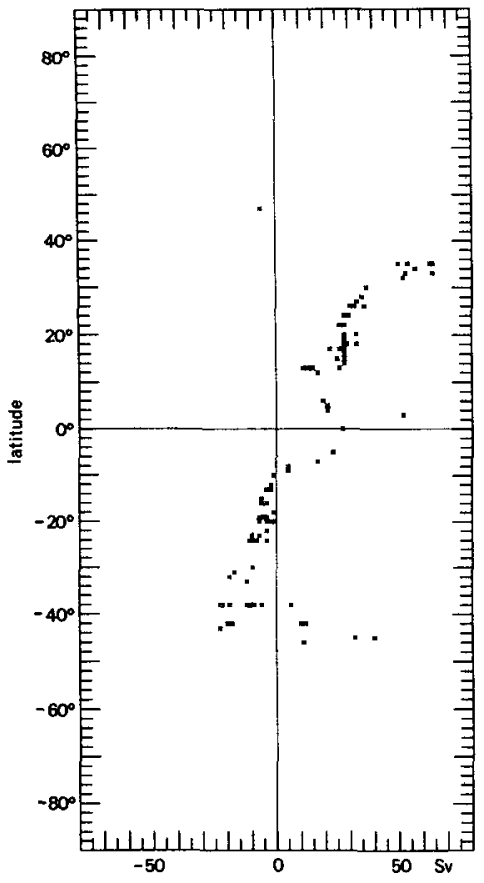

FIG. 1. Observed upper-ocean WBC transports.

hemispheres of the Atlantic sector have been checked. Only a few of them point to the possibility of windinduced asymmetries, whereas others do not [Garner 1962 ( see also Neumann 1968); Veronis 1973; Mellor et al. 1982; Godfrey 1989]. In some cases these asymmetries are confined to the equator where the nonzero zonally integrated wind stress curl causes a northward WBC transport of up to $10 \mathrm{~Sv}$ (Han 1984b; Joyce 1988 ). Other models reveal strong asymmetries with respect to the $\mathrm{FC}$ and the $\mathrm{BC}$, but opposite to observations; the $\mathrm{BC}$ is more intense than the $\mathrm{FC}$ (Welander 1959; Bye and Sag 1972; Bryan and Cox 1972; Han 1984a). No model study known to the author proves or disproves that there is a relation between WBC asymmetries and the shape of coastlines. A possible candidate causing such a coastline-controlled western boundary flow is the most eastern tip of South America (Cabo Branco), which may induce a splitting of the South Equatorial Current into NBC and BC (cf. Peterson and Stramma 1991, Fig. 18). Hence, special attention will be focused on that circumstance in this study.

Stommel $(1957,1965)$ presented a conceptual model explaining the observed WBC asymmetries to be the result of a superposition of wind-driven and thermohaline circulation. He considered an Atlantic Ocean divided into two layers by a level surface at $1500 \mathrm{~m}$, where the wind-driven circulation was confined to the upper layer. The thermohaline circulation was modeled as a prescribed vertical flux across the level surface. This flux was directed downward in subarctic areas and compensated by upward flux, the major part of which upwelled in the subantarctic areas and compensated by upward flux, the major part of which upwelled in the subantarctic area and some in subtropical latitudes of the North Atlantic. Mass conservation of upper- and lower-layer waters then required a WBC transport connecting source and sink regions in every layer. In the upper layer, this thermohaline-driven WBC was directed to the north all along the American continent. As this flow was superimposed on the winddriven WBC, it enhanced the NASBC and weakened the $\mathrm{BC}$. In addition, a northward equator-crossing WBC was required. This concept has been extended to global scale by Gordon (1986) in his "conveyor belt" theory based on water mass analyses. He proposed sinking of water at high latitudes in the North Atlantic and compensating upward flux all over the World Ocean. The return flow of water to the Atlantic, which has upwelled in the Pacific and Indian Oceans, occurred primarily via the Agulhas Current $(\mathrm{AgC}$, the "warm water" route) and to a lesser extent via the flow through Drake Passage (the "cold water" route). In the Atlantic, the upper-layer flow then followed the same path as in Stommel's concept along the American coast. In contrast, Broecker (1991) favored the "cold water" route to be the more important one, which is also confirmed by Rintoul's (1991) inverse calculations.

Only a limited number of thermohaline-driven numerical models exists from which conclusions about the impact of thermohaline flow on Atlantic WBC transports can be drawn. The domain of such models has to extend at least over both Atlantic hemispheres; thus, the relevant information can in principle be gained from global circulation models, but in all those studies the numbers distinguishing between WBC transports in the upper and the deep ocean are missing. Bryan et al. (1975) compared only the depth integrated transports of various WBCs, and the same information is contained in the total streamfunction values for the North and South Atlantic subtropical gyres displayed by Semtner and Chervin (1988) and in time series of barotropic WBC transports shown by Semtner and Chervin (1992). The latter study yields a total mean transport of the cross-equatorial NBC transport of $\sim 20 \mathrm{~Sv}$, the $\mathrm{BC}$ transport at $40^{\circ} \mathrm{S}$ is $75 \mathrm{~Sv}$ and that of the Florida Current at $35^{\circ} \mathrm{N}$ only $30 \mathrm{~Sv}$ (their Fig. $20)$. Even after removal of the contribution of the deep WBC to these numbers, the upper-ocean BC is still about 50\% stronger than the corresponding FC transport. A similar unrealistic behavior emerges also from the LC; the model diagnoses a mean transport around $40 \mathrm{~Sv}$-one order of magnitude larger than observed. Unfortunately, the authors did not discuss these serious discrepancies between observed and modeled WBC transports. Thus, it can only be conjectured that these are caused by the poor treatment of convection in high latitudes, that is, an underrepresentation of the thermohaline circulation. 
At present, we know that water is removed from the upper ocean by deep convection at high latitudes and resupplied by upwelling at other places of the ocean. First-order concepts of thermocline theories (Veronis 1981 ) yield an overall upwelling velocity on the order of $10^{-7} \mathrm{~m} \mathrm{~s}^{-1}$, the effect on the stratification of which is balanced by downward vertical diffusion of heat. The locations, where deep-water production by convective processes occurs, are rather well known, but only crude estimates of the production rates exist. According to Killworth (1983), convection areas are confined to the Antarctic continental shelf and the Weddell Sea in the Southern Hemisphere and the Labrador, Iceland, and Greenland Seas in the North Atlantic, where Antarctic Bottom Water and North Atlantic Deep Water, respectively, are generated. Recent estimates suggest a production rate of about $20 \mathrm{~Sv}$ for the North Atlantic Deep Water and $4 \mathrm{~Sv}$ for the Antarctic Bottom Water (Broecker 1991).

As long as WBC transports predicted by global-scale circulation models do not match observed numbers tolerably, and as long as WBC asymmetries are not reproduced at least qualitatively, it cannot be expected that such models offer any explanation of what might cause these asymmetries. Hence, in this study a simple model is presented based on Stommel's (1957, 1965) idea of dividing the Atlantic into two layers: the flow in the lower layer is purely thermohaline driven and in the upper layer the thermohaline "return flow" is superimposed on the wind-driven flow. Only the upper layer will be considered. The wind-driven flow there is evaluated by applying the Sverdrup equation relating the meridional flow to the curl of the wind stress. In an analogous manner as done by Stommel and Arons (1960) for the deep ocean, the thermohaline flow component is specified in terms of a given distribution of sinks and sources at the lower boundary of the upper layer representing the removal of upper-layer water by deep convection and replenishment by upwelling, respectively. Finally, the WBC transport is obtained as a volume-conserving balance of the ocean interior.

\section{The model}

\section{a. Equations}

In spherical coordinates, the stationary and vertically integrated linearized vorticity equation reads

$$
V(\lambda, \varphi)=\frac{1}{\rho \beta}(\nabla \times \vec{\tau})_{z}-w R \tan \varphi,
$$

assuming hydrostatic balance and neglecting horizontal friction and tidal forces. Here $\beta=(2 / R) \Omega \cos \varphi$ is the meridional gradient of the Coriolis parameter,

$$
(\nabla \times \vec{\tau})_{z}=\frac{1}{R \cos \varphi}\left[\frac{\partial \tau_{\varphi}}{\partial \lambda}-\frac{\partial}{\partial \varphi}\left(\tau_{\lambda} \cos \varphi\right)\right]
$$

is the vertical component of the curl of the wind stress vector $\vec{\tau}=\left(\tau_{\lambda} \tau_{\varphi}\right)$, and $U=\int_{-d}^{\eta} u d z$ and $V=\int_{-d}^{\eta} v d z$ are the velocity components vertically averaged between the depth $z=-d$, where the Ekman vertical velocity vanishes, and the sea surface at $z=\eta$. The other symbols used have the conventional meanings:

$$
\begin{array}{ll}
R & \text { earth radius }=6371 \mathrm{~km} \\
u & \text { zonal velocity } \\
v & \text { meridional velocity } \\
z & \text { vertical coordinate, increasing upward } \\
\varphi & \text { latitude }=0 \text { at the equator, increasing northward } \\
\lambda & \text { longitude }=0 \text { at the Greenwich meridian, increas- } \\
& \text { ing eastward } \\
\rho & \text { density of water }=1000 \mathrm{~kg} \mathrm{~m}^{-3} \\
\Omega & \text { rotation frequency of the earth }=7.27 \times 10^{-5} \mathrm{~s}^{-1} .
\end{array}
$$

Equation (1) is what Stommel (1965) called "the vorticity equation with a thermohaline process." In a meridionally bounded basin the vertically integrated zonal velocity at any constant latitude $\varphi=\varphi_{0}$ is obtained by integrating the continuity equation from the eastern boundary, $\lambda_{E}$, assuming zero normal velocity there:

$$
\begin{aligned}
U\left(\lambda, \varphi_{0}\right)=-\frac{\partial}{\partial \varphi} \int_{\lambda_{E}}^{\lambda} V \cos \varphi d \lambda^{\prime} \\
\\
+R \cos \varphi_{0} \int_{\lambda_{E}}^{\lambda} w\left(\lambda^{\prime}, \varphi_{0}\right) d \lambda^{\prime} .
\end{aligned}
$$

\section{b. Boundary conditions and western boundary currents}

For simplicity, we consider first our model domain as a layer of water of constant thickness $H$ (Fig. 2) bounded by meridians $\lambda_{W}$ and $\lambda_{E}$ on the western and eastern boundary and by latitude circles $\varphi_{S}$ and $\varphi_{N}$ in the south and the north. No normal flow is allowed at these boundaries. The interior flow is completely determined by (1) and (2), if the forcing functions $\vec{\tau}(\lambda, \varphi)$ at the top and $w(\lambda, \varphi)$ at the bottom of the layer are known. To keep the water volume of the model domain at a constant value, the net vertical volume transport across the bottom must vanish:

$$
\int_{\varphi_{S}}^{\varphi_{N}} \int_{\lambda_{W}}^{\lambda_{E}} w \cos \varphi d \lambda d \varphi=0
$$

Because the integration of (2) starts at the eastern boundary, continuity is satisfied everywhere in the model domain except at the western boundary. Therefore, an infinitesimally wide western boundary layer is defined, where a WBC compensates for the meridional transport $T_{m}$ across this latitude circle in the interior and the net vertical volume transport $T_{v}$ to the south of this latitude. Hence, the WBC transport $T_{W}$ yields as

$$
T_{W}=T_{v}-T_{m},
$$



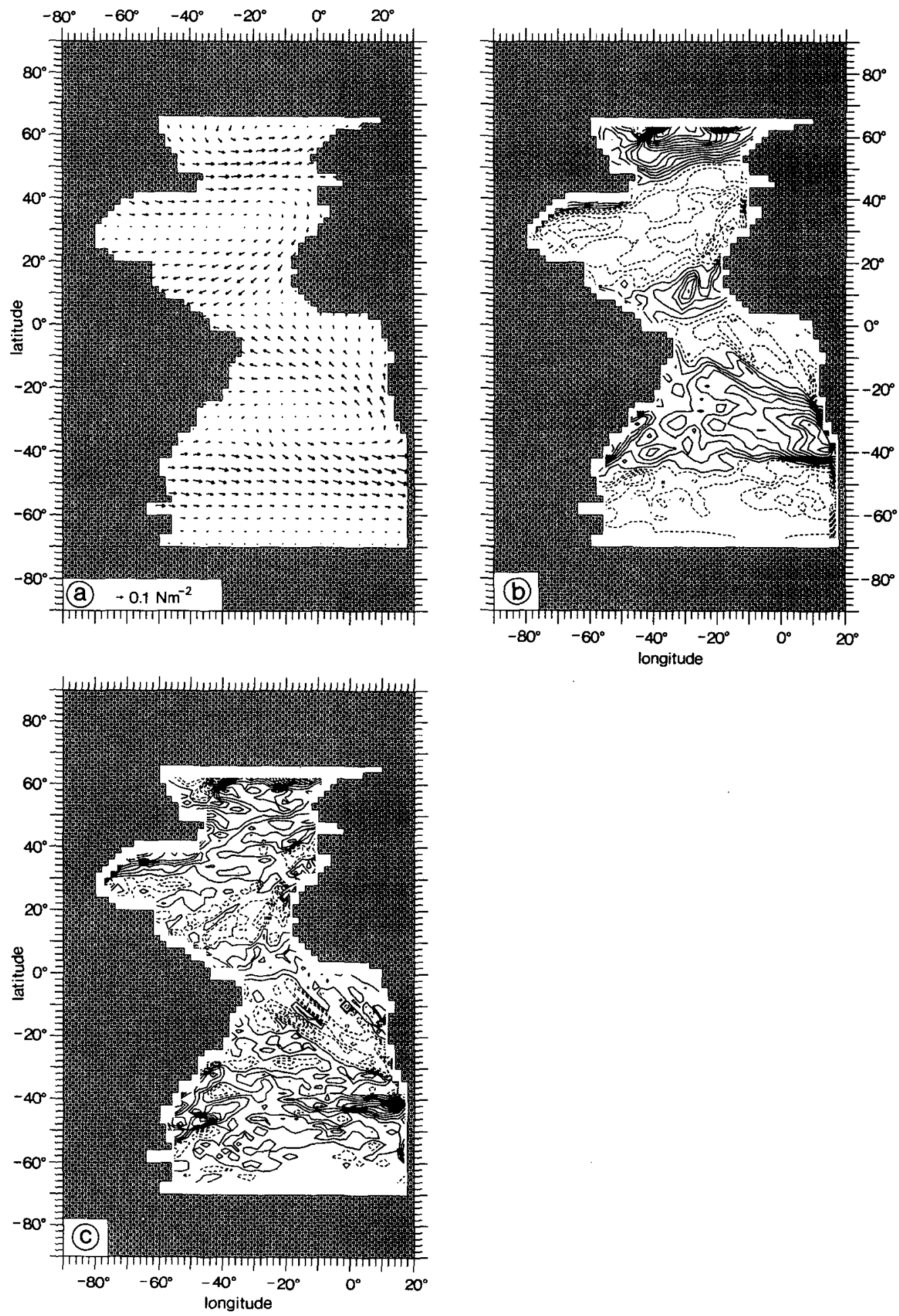

FIG. 3. Properties of the annual mean wind stress provided by Hellerman and Rosenstein (1983). (a) Distribution of stresses (stress A). (b) The wind stress curl $(\nabla \times \vec{\tau})_{z}$. Dashed lines mean negative values. The zero line is the first solid one. Contour interval is $0.1 \mathrm{~N} \mathrm{~m}^{-3} \mathrm{rad}^{-1}$. (c) The meridional derivative of the wind stress curl $\partial(\nabla \times$ $\vec{\tau})_{z} / \partial \varphi$. Dashed lines mean negative values. The zero line is the first solid one. Contour interval is $5 \cdot 10^{-7} \mathrm{~N} \mathrm{~m}^{-3}$ $\mathrm{rad}^{-2}$. 


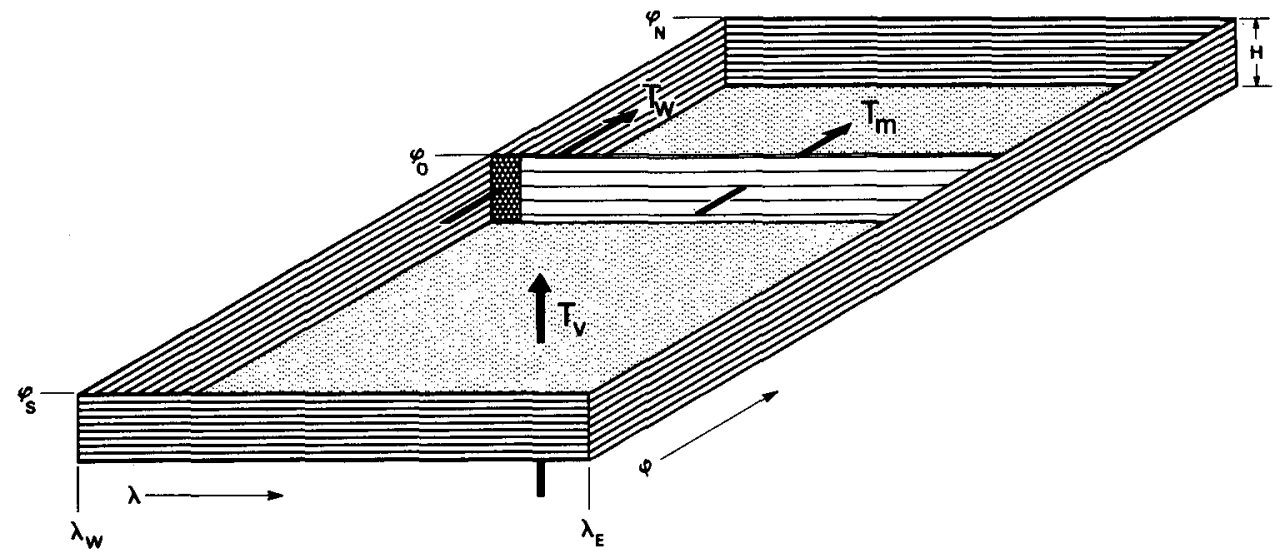

FIg. 2. An idealized model domain. For explanation of symbols see text. The width of the western boundary layer (heavy shading) is infinitesimally small.

where

$$
T_{v}=R^{2} \int_{\varphi_{S}}^{\varphi_{0}} \int_{\lambda_{W}}^{\lambda_{E}} w \cos \varphi d \lambda d \varphi
$$

and

$$
T_{m}=R \int_{\lambda_{W}}^{\lambda_{E}} V \cos \varphi d \lambda
$$

\section{c. Basin geometry}

In the model, ( 1 ) and (2) will be solved numerically on a $C$ grid with $\Delta \lambda \times \Delta \varphi=2^{\circ} \times 2^{\circ}$. Two different closed basins will be used as model domains. Basin A (cf. Fig. 5a) is a "rectangular" box symmetric about the equator and bounded by latitude circles $\varphi_{S}=66^{\circ} \mathrm{S}$ and $\varphi_{N}=66^{\circ} \mathrm{N}$ and meridians $\lambda_{W}=88^{\circ} \mathrm{W}$ and $\lambda_{E}$ $=18^{\circ} \mathrm{E}$. It will be used for some preliminary experiments illustrating basic features of circulation patterns in a double-hemispheric ocean. Basin B (cf. Fig. 5b), taking into account the irregular shape of the coastlines of the continents to first-order approximation, is zonally bounded at $\varphi_{S}=70^{\circ} \mathrm{S}$ and $\varphi_{N}=68^{\circ} \mathrm{N}$. The meridional boundaries are given by the $200-\mathrm{m}$ isobaths. The Strait of Gibraltar and the passages through the Antilles Archipelago are closed; that is, the Caribbean and the Gulf of Mexico are treated as land.

\section{d. The Circumpolar and the Agulhas Currents}

A serious problem in defining boundary conditions arises in the Southern Ocean: To maintain continuity, the volume fluxes through Drake Passage and between Cape Agulhas and Antarctica have to compensate for each other. Thus, if the transport through either of these passages is set, the compensating flow through the other passage is fixed automatically. On the other hand, (2) requires the zonal flow at the western boundary to depend on the integrated meridional and vertical volume transports in the interior. To overcome this problem, the zonal flow through both passages is blocked by meridional walls, but inflow / outflow due to the Circumpolar Current $(\mathrm{CC})$ and the leakage of the $\mathrm{AgC}$ from the Indian into the Atlantic Ocean are enabled by definition of vertical transports occurring at the respective latitude in the grid cells next to the walls, which supply water to the basin in Drake Passage (CC) and close to the southern tip of Africa (AgC) and extract the same amount along the barrier between the southern extension of the AgC and Antarctica.

\section{e. Wind stress}

Three different wind stresses based on annual mean distributions provided by Hellerman and Rosenstein (1983) on a $2^{\circ} \times 2^{\circ}$ grid are used. Stress A (Fig. 3a) contains the original pattern of zonal and meridional stresses and will be applied to Basin B only. Stresses B and C (Fig. 4a,b) are purely zonal. Stress B has been calculated from stress $A$ by averaging the zonal component across Basin B excluding stresses over land. Stress $C$ has been derived from stress $B$ by first replacing the zonal stresses at every latitude by the mean stress calculated from the stress at this latitude and the corresponding stress in the opposite hemisphere. In a second step, the graph has been smoothed using a spectral filter. Thus, stress $\mathrm{C}$ is symmetric about the equator, stress B contains inequalities of the zonal wind stress pattern for the Northern and the Southern Hemispheres, and stress A provides the full information. Figures 3 and 4 also display the wind stress curl and its meridional derivative, which are the quantities determining the wind-driven part of the meridional and zonal velocities, respectively.

\section{$f$. Thermohaline forcing and treatment of concentrated sources and sinks}

Thermohaline forcing is introduced by the vertical speed $w$ at the lower boundary of the domain acting 


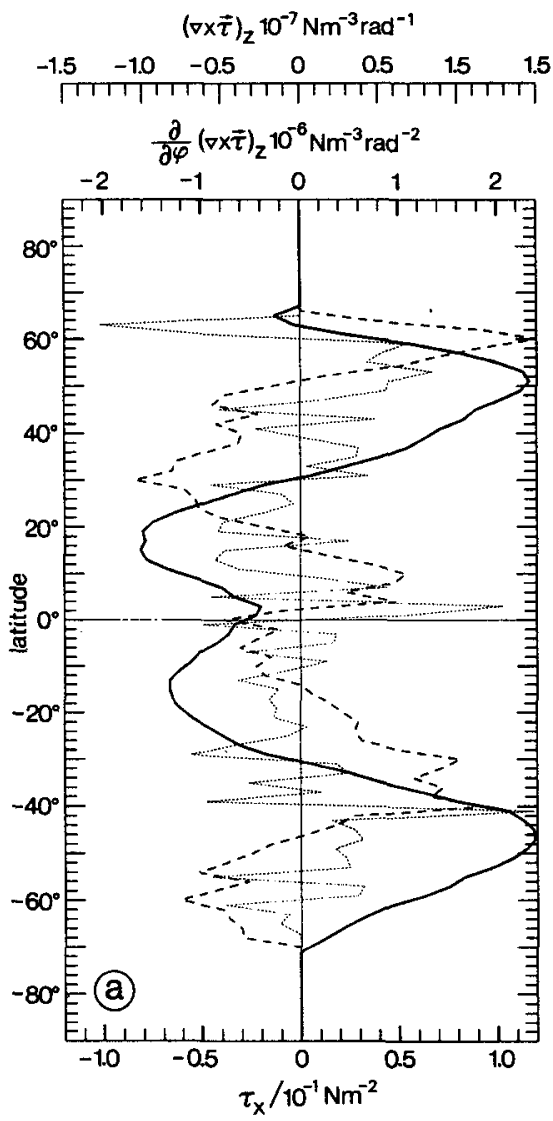


(Fig. 6a, left panel), which is also symmetric about the equator. The strongest poleward transports of $\sim 45 \mathrm{~Sv}$ occur in the western boundary layers of the subtropical gyres. The subpolar WBCs are somewhat weaker, $\sim 40 \mathrm{~Sv}$. There are two WBCs left closing the cyclonic tropical gyres. For the present they will be named South Tropical Current and North Tropical Current. Their equatorward directed transport lies close to $15 \mathrm{~Sv}$.

\section{2) W2: RESPONSE DUE TO THE CIRCUMPOLAR CURRENT AND AGULHAS CURRENT}

In $W 2$, inflow due to the $C C$ is defined by a vertical volume transport of $50 \mathrm{~Sv}$ distributed over two grid cells between $56^{\circ}$ and $60^{\circ} \mathrm{S}$ at the western model boundary (Fig. Sa). The second inflow of $10 \mathrm{~Sv}$ representing the $\mathrm{AgC}$ occurs in a single grid cell centered at $35^{\circ} \mathrm{S}$ at the eastern boundary. The total inflow of $60 \mathrm{~Sv}$ is compensated by downwelling distributed over the column of grid points adjacent to the eastern boundary between $36^{\circ} \mathrm{S}$ and $66^{\circ} \mathrm{S}$. The rates for inflow/ outflow are estimates based on Peterson and Stramma (1991).

The streamfunction and WBC transport are displayed in Fig. 6b. For comparison, the WBC transport of $\mathrm{W} 1$ has been added in the left panel. The openings of Drake Passage and the passage between Cape Agulhas and Antarctica have only affected the latitude range south of $34^{\circ} \mathrm{S}$. This is trivial because the balance for the horizontal transport [(1) and (2)] has only been changed south of this latitude according to $w$. The same is true for the WBC transport, which is modified there according to nonzero vertical transport $T_{v}$. The $\mathrm{AgC}$ now feeds into the South Atlantic subtropical gyre enhancing the $\mathrm{BC}$ by $10 \mathrm{~Sv}$ at $36^{\circ} \mathrm{S}$, which is exactly the amount of water added to the basin north of this latitude by the $\mathrm{AgC}$ inflow. South of $36^{\circ} \mathrm{S}$, the interior flow field is controlled by the superposition of meridional flow depending on the wind stress curl only (because $w=0$ in the interior) and the zonal flow modified by the sources at the eastern boundary. This creates a $\mathrm{CC}$ and makes the subpolar gyre nearly disappear. For latitudes between $36^{\circ} \mathrm{S}$ and the southern latitude of Drake Passage, $T_{v}$ is positive leading to an intensification of the MC, the maximum transport of which is now close to $70 \mathrm{~Sv}$. To the south of Drake Passage, there is a net outflow to the Indian Ocean reducing the WBC transport there. Thus, the major part of the CC inflow through Drake Passage first turns north via the MC before turning east across the South Atlantic, a behavior that is also known from observations (Peterson and Stramma 1991, Fig. 2).

\section{3) W3: RESPONSE TO ASYMMETRIC WIND STRESS}

Run W3 is a repetition of W2 except that now an asymmetric wind stress pattern (stress B) is applied as the driving force. Comparison of Figs. $6 \mathrm{~b}$ and $6 \mathrm{c}$ shows
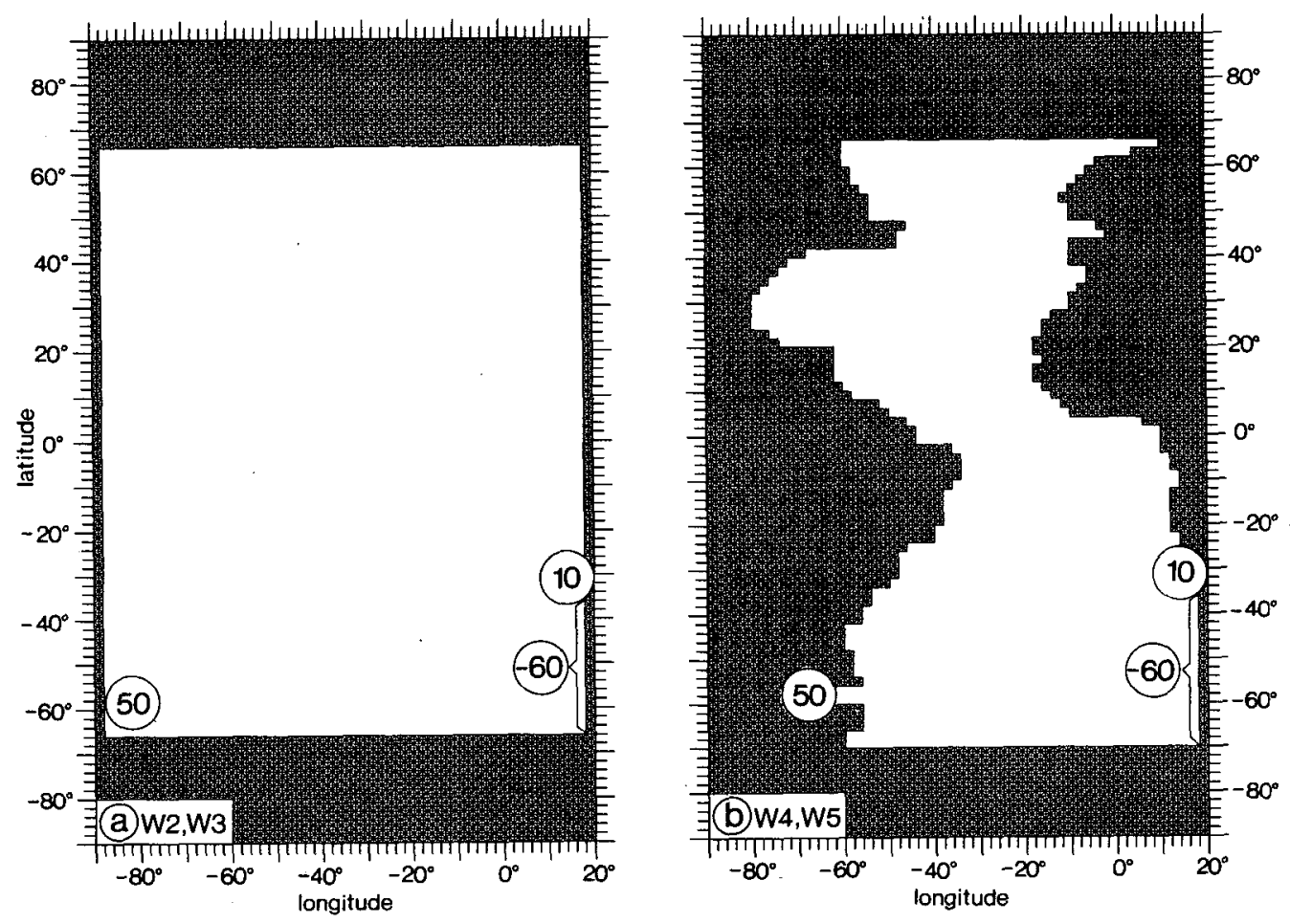

FIG. 5. Location and strength of concentrated sources and sinks in the Southern Ocean for model runs (a) W2, W3 and (b) W4, W5. Numbers refer to vertical volume transport (in Sv). 

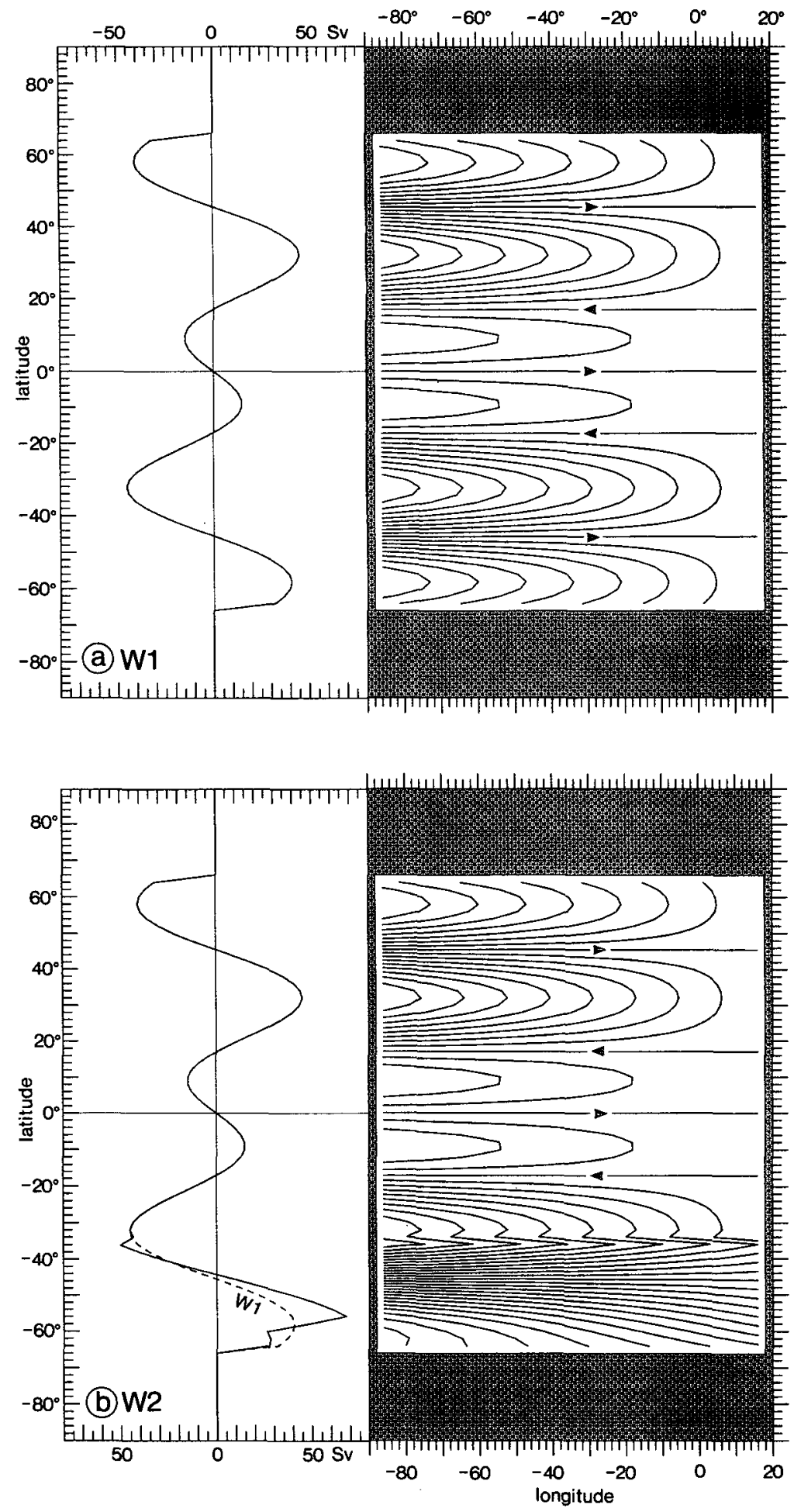

FiG. 6. Results of the purely wind-driven model runs $\mathrm{W} 1, \ldots$, W5 for (a) W1: Basin A, stress C; (b) W2: Basin A, stress C, Circumpolar and Agulhas Currents defined by concentrated sinks/sources; (c) W3: Basin A, stress B; (d) W4: Basin B, stress B; 

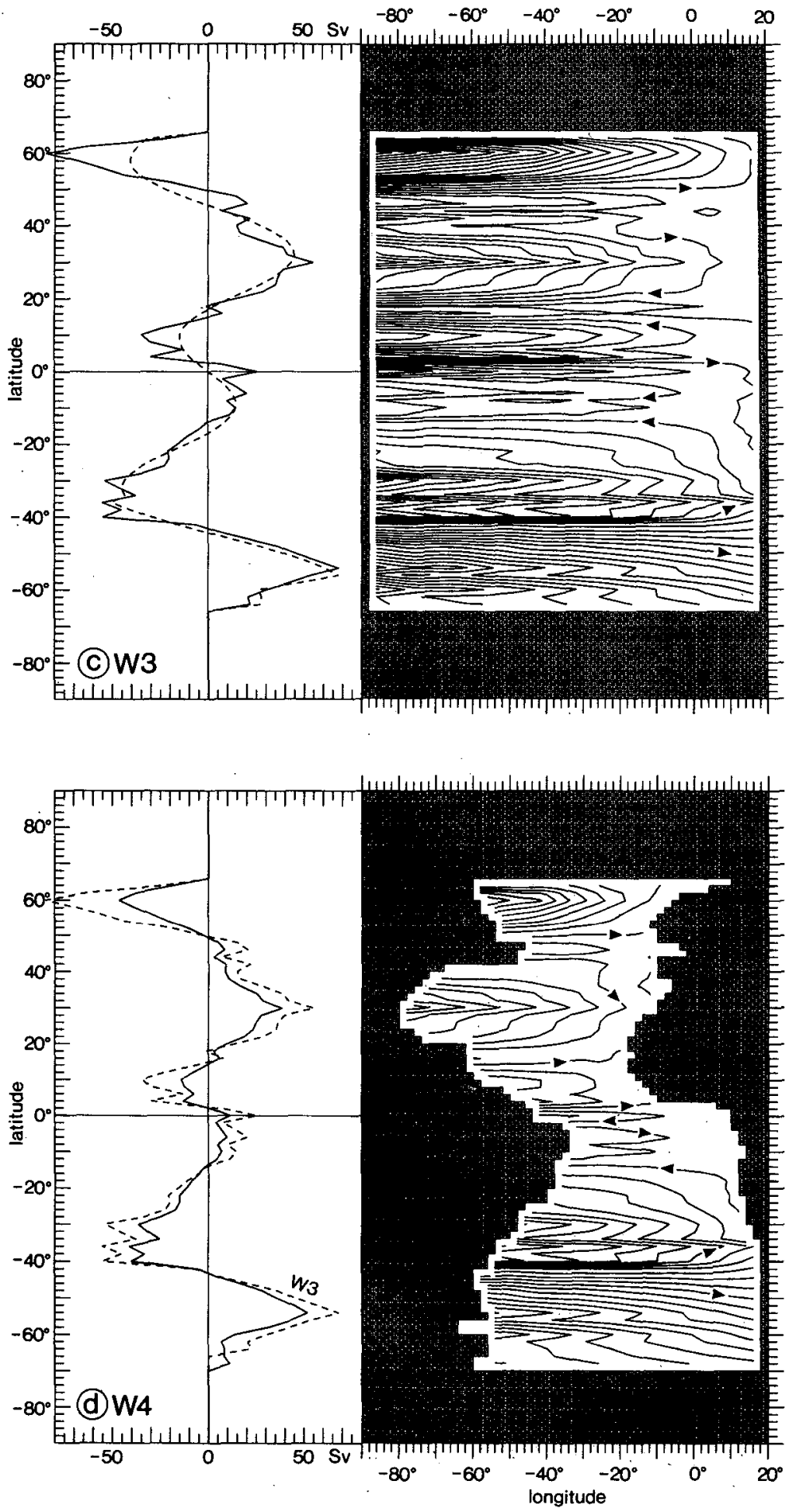

FIG. 6. (Continued) and (e) W5: Basin B, stress A. Right panel: The volume transport streamfunction. Contour interval is $10 \mathrm{~Sv}$. Left panel: The corresponding western boundary current transports, $T_{W}$. Transport patterns from preceding runs have been added as dashed lines and are labeled by denotation of that run. 


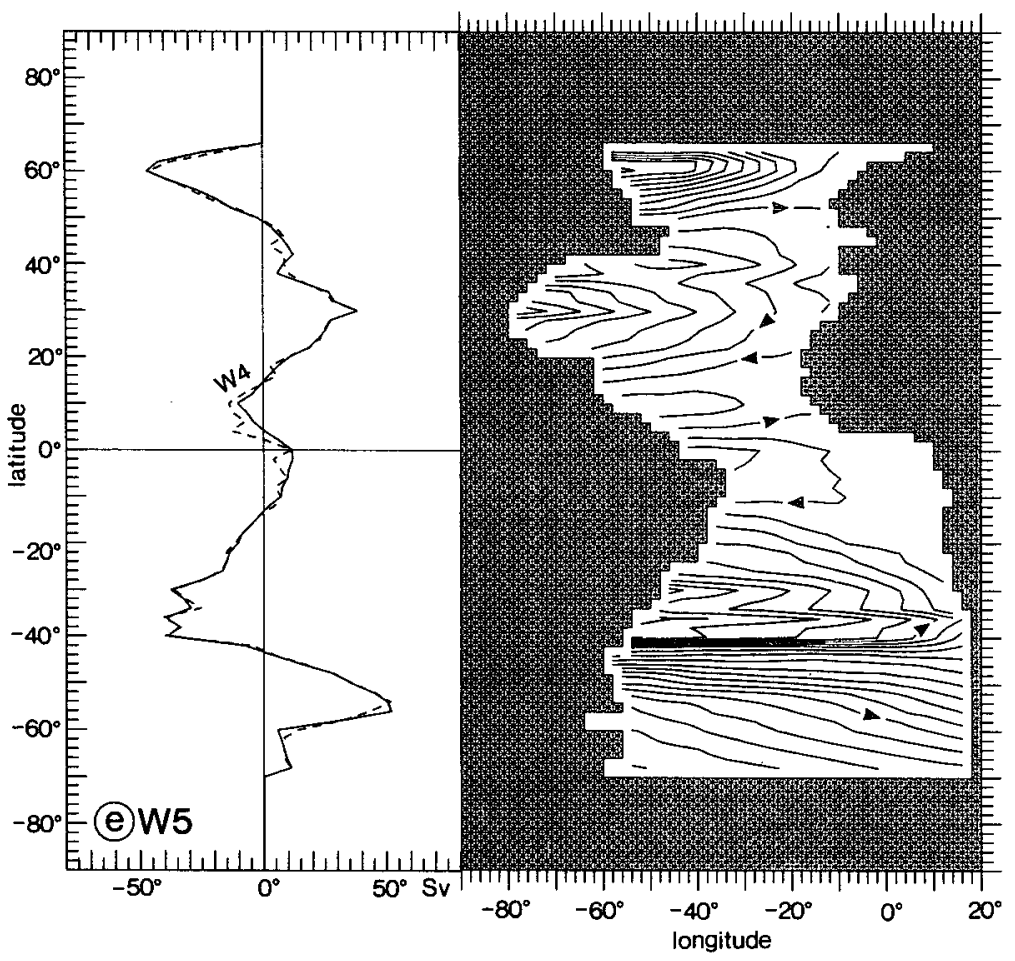

FIG. 6. (Continued)

that the gross shape of the meridional flow is preserved, but the zonal flow pattern reveals a multiple structure of zonal flow bands of different intensities and directions. This high-wavenumber noise is caused by spatial fluctuations of the meridional derivative of the wind stress curl (cf. Fig. 4a). Because $T_{W}$ depends on $V$, the WBC curve is reflecting the meridional finestructure of the curl, the wavenumber of which is lower than that of its derivative. Except for the enhanced LC ( $\sim 92$ $\mathrm{Sv})$ and the North Tropical Current $(\sim 32 \mathrm{~Sv})$ transports due to asymmetries of the amplitudes of the wind stress curl at the respective latitudes, the WBC structure is very similar to that of W2. Additionally, the nonzero curl of stress B at the equator leads to a boundary current of $\sim 23 \mathrm{~Sv}$ directed from the Southern to the Northern Hemisphere.

\section{4) W4: EFFECT OF COASTAL BOUNDARIES}

In a purely wind-driven ocean, the WBC transport depends solely on the zonally integrated meridional transport $T_{m}$. To check how much a different pathlength of the integral changes the WBC structure, W4 is a repetition of $\mathrm{W} 3$ but using the more realistic boundaries of Basin B. The resulting transport streamfunctions and WBC transports are shown in Fig. 6d.

In comparison with $\mathrm{W} 3$, the general flow pattern has been preserved, but the strength of all gyres has been weakened, which is expressed by a decreased WBC intensity. In the tropical and subtropical regions there did not arise further asymmetries between both hemispheres as a consequence of modified basin boundaries. The North and South Tropical Currents and the crossequatorial boundary current have been reduced by about a factor of 2 . Peak values of the subtropical WBCs, NASBC and BC, are $\sim 38 \mathrm{~Sv}$ and $\sim 40 \mathrm{~Sv}$, respectively. A significant difference in reduction of transport can be seen in the subpolar WBCs. The MC decreased only from $\sim 59$ Sv to $\sim 52 \mathrm{~Sv}$, whereas the $\mathrm{LC}$ has shrunk to about half its $\mathrm{W} 3$ value from $\sim 83$ Sv to $\sim 46 \mathrm{~Sv}$, so that both subpolar WBC transports are now at about the same magnitude.

\section{5) W5: THE WIND-DRIVEN CIRCULATION}

In the final only wind-driven run (Fig. 6e), stress A is applied to Basin B. Both the streamfunction and the WBC transport are very similar to those in W4. The only difference worth mentioning is the North Tropical Current reduced somewhat in size and meridional extent.

The structure of the Atlantic WBCs as resulting from climatological wind stress can be described as follows: The equatorward subpolar boundary is restricted to the latitude range between $44^{\circ} \mathrm{S}$ and $70^{\circ} \mathrm{S}$, and between $50^{\circ} \mathrm{N}$ and $66^{\circ} \mathrm{N}$, respectively, where the poleward limit is given by the model zonal boundaries. This interhemispheric asymmetry in latitudinal extent is caused by the different widths of cyclonic wind stress curl (Fig. 4a). Peak values of transport are close to $50 \mathrm{~Sv}$. Max- 


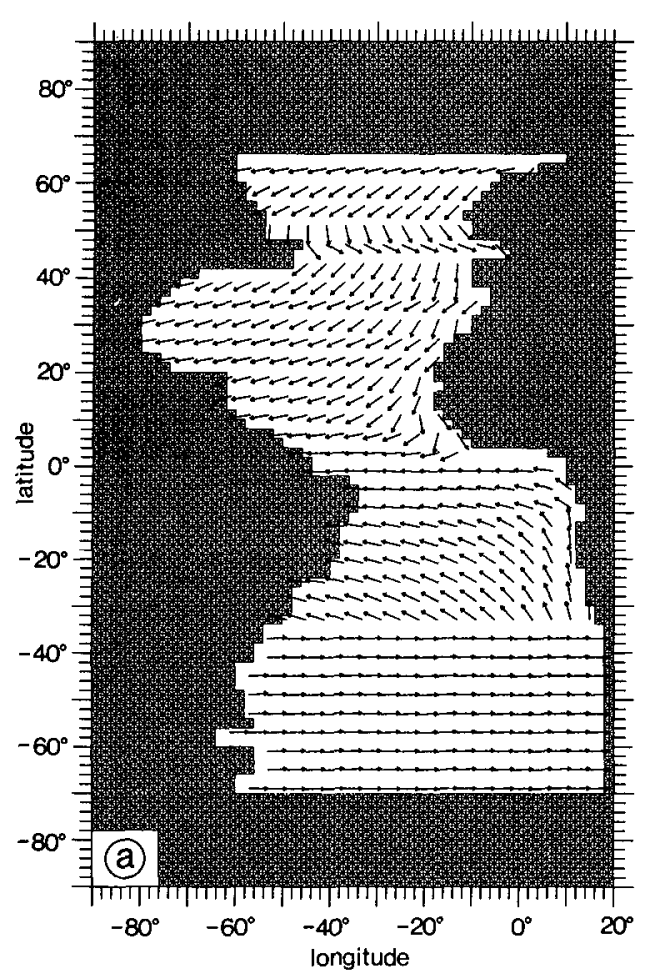

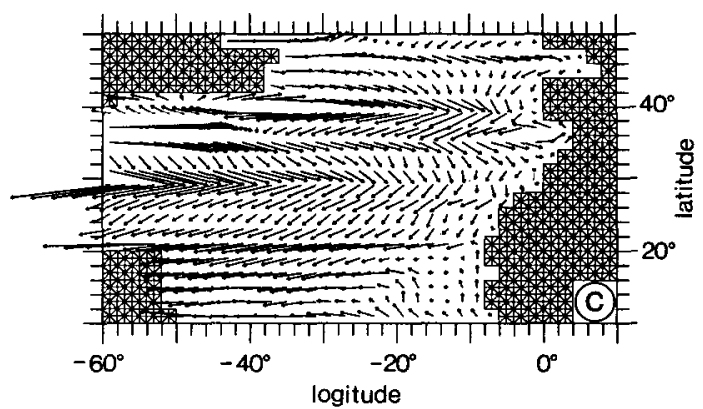

FIG. 7. T1: Horizontal flow patterns of superimposed wind-driven and thermohaline flows. (a) The direction of the thermohaline-driven flow. (b) Thermohaline-driven horizontal volume transport. (c) Wind-driven horizontal volume transport. The same scaling is used in (b) and (c).

imum transports of the subtropical boundary currents $\mathrm{BC}(\sim 42 \mathrm{~Sv})$ and NASBC $(\sim 38 \mathrm{~Sv})$ are also nearly symmetric, but the NASBC meridional extent is about $5 \mathrm{deg}$ wider due to anticyclonic wind stress curl at higher latitudes in the Northern Hemisphere. The only significant asymmetry caused by the wind is restricted to the tropical boundary currents. The North Tropical Current extends over about 10 deg between $4^{\circ} \mathrm{N}$ and $14^{\circ} \mathrm{N}$ and has a maximum transport of $\sim 10 \mathrm{~Sv}$ at about $10^{\circ} \mathrm{N}$. The South Tropical Current, however, is not confined to the Southern Hemisphere but is crossing the equator. It extends over about $17 \mathrm{deg}$ from $13^{\circ} \mathrm{S}$ to $4^{\circ} \mathrm{N}$ and has a maximum transport value of $\sim 12 \mathrm{~Sv}$ just at the equator.

\section{b. Thermohaline effects}

In the preceding section, the upper-ocean flow has been assumed to be divergence free; thus, $w \equiv 0$ except at those locations where a vertical volume flux has been introduced to establish the $\mathrm{CC}$ and the $\mathrm{AgC}$. But in reality, the flow is divergent due to the thermohaline part of the circulation, the impact of which on the WBC transport will be investigated in this section.

In the following, four model runs numbered $\mathrm{T} 1$ to T4 ("T" means thermohaline) will be presented, each making different assumptions on the strength and dis- tribution of the concentrated sinks/sources. The common base for all runs is run W5; hence, only deviations from this "basic state" caused by varying thermohaline forcing will be considered.

\section{1) T1: Sinking IN THE NoRTH ATLANTIC}

In this run, thermohaline forcing is defined by a concentrated sink in the northeast corner of the model domain representing deep convection in the Labrador, Greenland, and Iceland Seas, which occur at approximately the same latitude. The sink is centered at $\lambda$ $=9^{\circ} \mathrm{E}, \varphi=65^{\circ} \mathrm{N}$ and extracts water from the upper ocean at a rate of $20 \mathrm{~Sv}$, which is resupplied by uniform upwelling of $2.7 \times 10^{-7} \mathrm{~m} \mathrm{~s}^{-1}$ over the rest of the model domain. The resulting thermohaline circulation pattern for the case $\vec{\tau} \equiv 0$ is displayed in Fig. 7a. The zonal flow component is in general directed to the west except at the latitude circles of the Bay of Biscay and the Gulf of Cadiz, where eastward transport occurs due to the irregular shape of the coastlines, and south of $34^{\circ} \mathrm{S}$, where eastward transport is caused by the source/sink distribution establishing the $\mathrm{CC}$. To give an impression of the strength of the flow in the ocean interior, Figs. $7 \mathrm{~b}$ and $7 \mathrm{c}$ show that except for a few locations the thermohaline transport in the central North Atlantic is about one order of magnitude less than the winddriven volume transport. 
The above statement is not valid for the WBC transports. Comparison of $\mathrm{T} 1$ with W5 (Fig. 8a) reveals that the WBC pattern is altered significantly by adding a thermohaline contribution. North of $30^{\circ} \mathrm{S}$ the thermohaline WBC adds northward transport to the winddriven WBC. South of that latitude, the opposite can be seen. This sign change of the thermohaline-driven WBC is a typical feature for boundary current flows on a sphere driven by source/sink distributions. By applying (4) to the thermohaline WBC only, this means that in the Southern Ocean the loss due to the equatorward flow in the interior is not completely balanced by upwelling, which requires this net loss to be compensated by a southward-directed WBC. This strengthens slightly the wind-driven $\mathrm{BC}$ south of the critical latitude by $\sim 5 \mathrm{~Sv}$ and weakens the MC transport by $\sim 10 \mathrm{~Sv}$. South of $61^{\circ} \mathrm{S}$, that is, in the Weddell Sea, the preexisting wind-driven boundary current even reverses sign and now flows to the south. For all latitudes north of $30^{\circ} \mathrm{S}$, however, there is an excess of water in the southern basin caused by interior upwelling and thermohaline meridional transport to be removed by a northward thermohaline WBC, the transport of which increases with progressing latitude. In the Southern Hemisphere, this shifts the beginning of the BC southward from $13^{\circ} \mathrm{S}$ to $17^{\circ} \mathrm{S}$ and increases the northward transport of South Tropical Current continuously to a peak value of more than $20 \mathrm{~Sv}$ crossing the equator.

North of the equator, the transport breaks down to less than $5 \mathrm{~Sv}$ at $\sim 10^{\circ} \mathrm{N}$ before it intensifies again. The breakdown is due to the preexisting wind-driven equatorward North Tropical Current, which has diminished completely. Hence, we may now attribute the name "North Brazil Current" to the equator-crossing boundary current. Farther north of the breakdown, the WBC intensifies steadily and reaches a maximum NASBC transport of $60 \mathrm{~Sv}$ at $30^{\circ} \mathrm{N}$-approximately $22 \mathrm{~Sv}$ more than in the purely wind-driven run W5. Due to the thermohaline part, the sign change of WBC transport occurs at $\sim 56^{\circ} \mathrm{N}$-about $7 \mathrm{deg}$ farther north than in W5. This has also lead to a LC nearly $30 \mathrm{~Sv}$ weaker than in W5 and reduced considerably in meridional extent. The weakening of about 1.5 times the strength of the sink at the northern boundary can be explained by the fact that, in addition to the deficit of $20 \mathrm{~Sv}$, another $\sim 10 \mathrm{~Sv}$ flowing south due to the uniform upwelling (cf. Figs. 7a,b) have to be resupplied by the WBC (cf. also Stommel and Arons 1960).

\section{2) T2: SiNKING IN THE NORTH ATLANTIC AND IN THE WEDDELL SEA}

In $\mathrm{T} 2$, another concentrated sink has been added taking into account deep convection in the Weddell Sea at a rate of $4 \mathrm{~Sv}$ (Fig. 8b). This leads to additional overall upwelling and intensification of thermohaline equatorward flow in the interior and modifies the WBC structure (Fig. $8 \mathrm{~b}$ ). South of $30^{\circ} \mathrm{N}$, the WBC graph is shifted to the left; that is, the peak transports of the northward $\mathrm{NBC}$ and $\mathrm{MC}$ are reduced by $\sim 2 \mathrm{~Sv}$ and $\sim 6 \mathrm{~Sv}$, respectively, and the peak transports of the southward directed BC and Weddell Sea boundary current are enhanced by an amount of $\sim 6 \mathrm{~Sv}$. To the north of $30^{\circ} \mathrm{N}$, the WBC transports are changed insignificantly.

\section{3) T3: INTEROCEAN EXCHANGE: THE "COLD WATER ROUTE"}

In $\mathrm{T} 1$ and $\mathrm{T} 2$, the upwelling transport compensating for the sinking at high latitudes occurs only in the Atlantic. In T3, however, it will be assumed that $15 \mathrm{~Sv}$ upwell outside the Atlantic and return as additional flow via Drake Passage (Fig. 8c). This is an extreme version of Broecker's (1991) "cold water route" return flow concept and has a dramatic effect on the WBCs, primarily in the Southern Hemisphere. The BC peak transport decreases from about $48 \mathrm{~Sv}$ to $30 \mathrm{~Sv}$ in comparison with $\mathrm{T} 2$ and reaches for the first time only half the value of the NASBC. In the same way also the meridional extent of the $\mathrm{BC}$ is reduced considerably. There is southward transport only between $20^{\circ} \mathrm{S}$ and $42^{\circ} \mathrm{S}$. In contrast, the $\mathrm{MC}$ has intensified to $\sim 60 \mathrm{~Sv}$ and increased in meridional extent. The Weddell Sea WBC has nearly disappeared. The cross-equatorial NBC transport has strengthened again and reaches an amplitude of about $27 \mathrm{~Sv}$.

\section{4) T4: INTEROCEAN EXCHANGE: THE "WARM WATER ROUTE"}

Run T4 favors Gordon's ( 1986) concept attributing the major part of the return flow to the "warm water route" via the $\mathrm{AgC}$. In the extreme case of $15 \mathrm{~Sv}$ return flow that would mean to increase the $\mathrm{AgC}$ transport to $25 \mathrm{~Sv}$ - a magnitude very much larger than has ever been observed. Thus, in $\mathrm{T} 4$ the $\mathrm{AgC}$ transport has been increased by only $5 \mathrm{~Sv}$ to $15 \mathrm{~Sv}$ and simultaneously the $\mathrm{CC}$ transport between Africa and Antarctica has been reduced by $10 \mathrm{~Sv}$, which yields a net inflow change of $15 \mathrm{~Sv}$ from the Indian Ocean into the Atlantic (Fig. 8d). In accordance, the Drake Passage inflow has been reduced by $15 \mathrm{~Sv}$ to $50 \mathrm{~Sv}$ as in T1, T2. In comparison with $\mathrm{T} 3$, this return flow change affects only the WBC structure south of $34^{\circ} \mathrm{S}$. The peak BC transport increases to about $35 \mathrm{~Sv}$, the MC has been reduced to about $48 \mathrm{~Sv}$, and there is no significant boundary current left in the Weddell Sea. Altogether, comparing the results of $T 3$ and $T 4$, neither the warm nor the cold water route can be favored because of insignificant differences.

\section{Comparison with observations}

Obviously, only the model runs containing a thermohaline flow component are able to reproduce the 

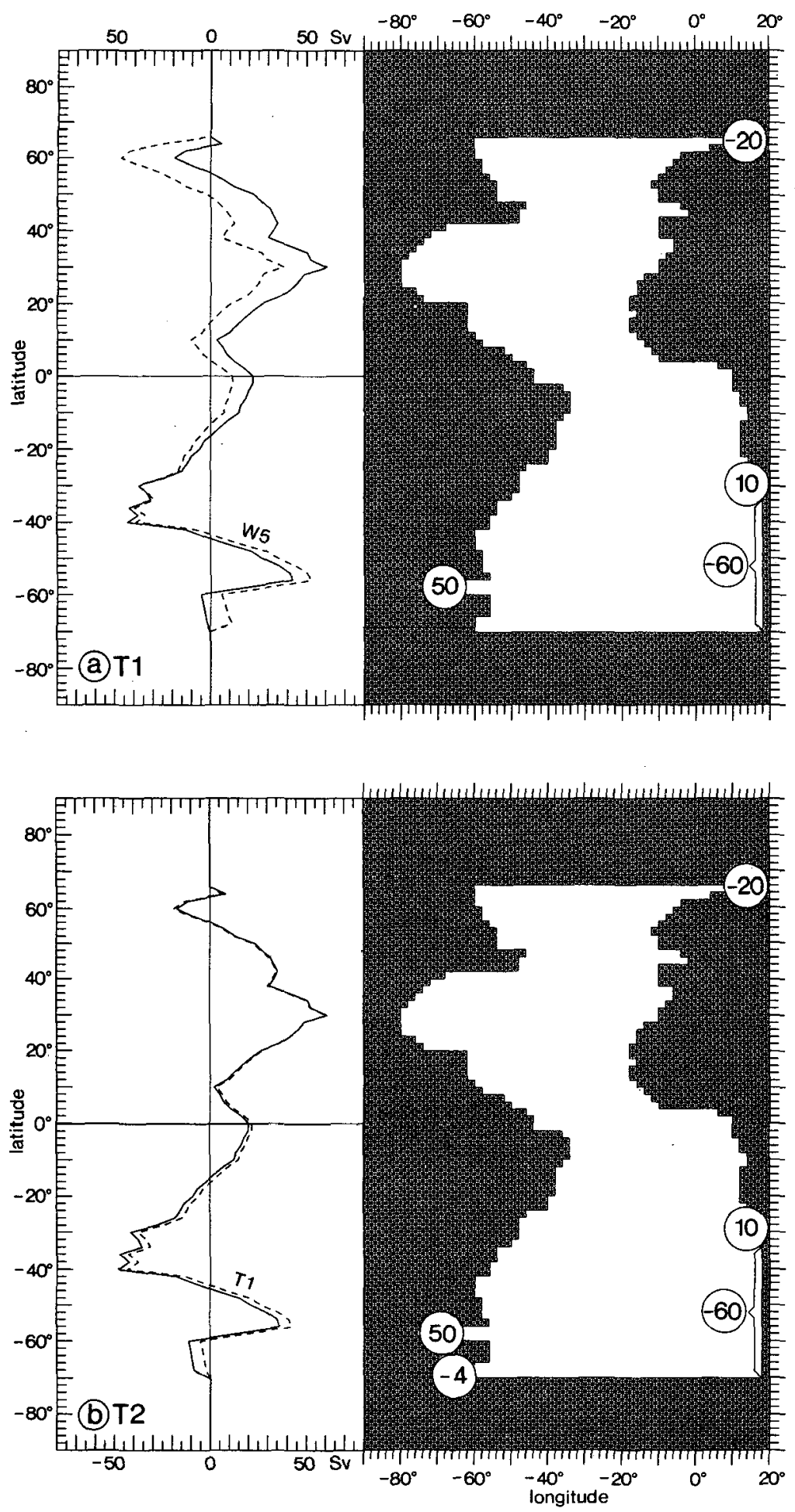

FIG. 8. Results of wind and thermohaline driven model runs T1, ., , T4. (a) T1: sinking in the North Atlantic, uniform upwelling over the Atlantic; (b) T2: additional sinking in the Weddell Sea. 

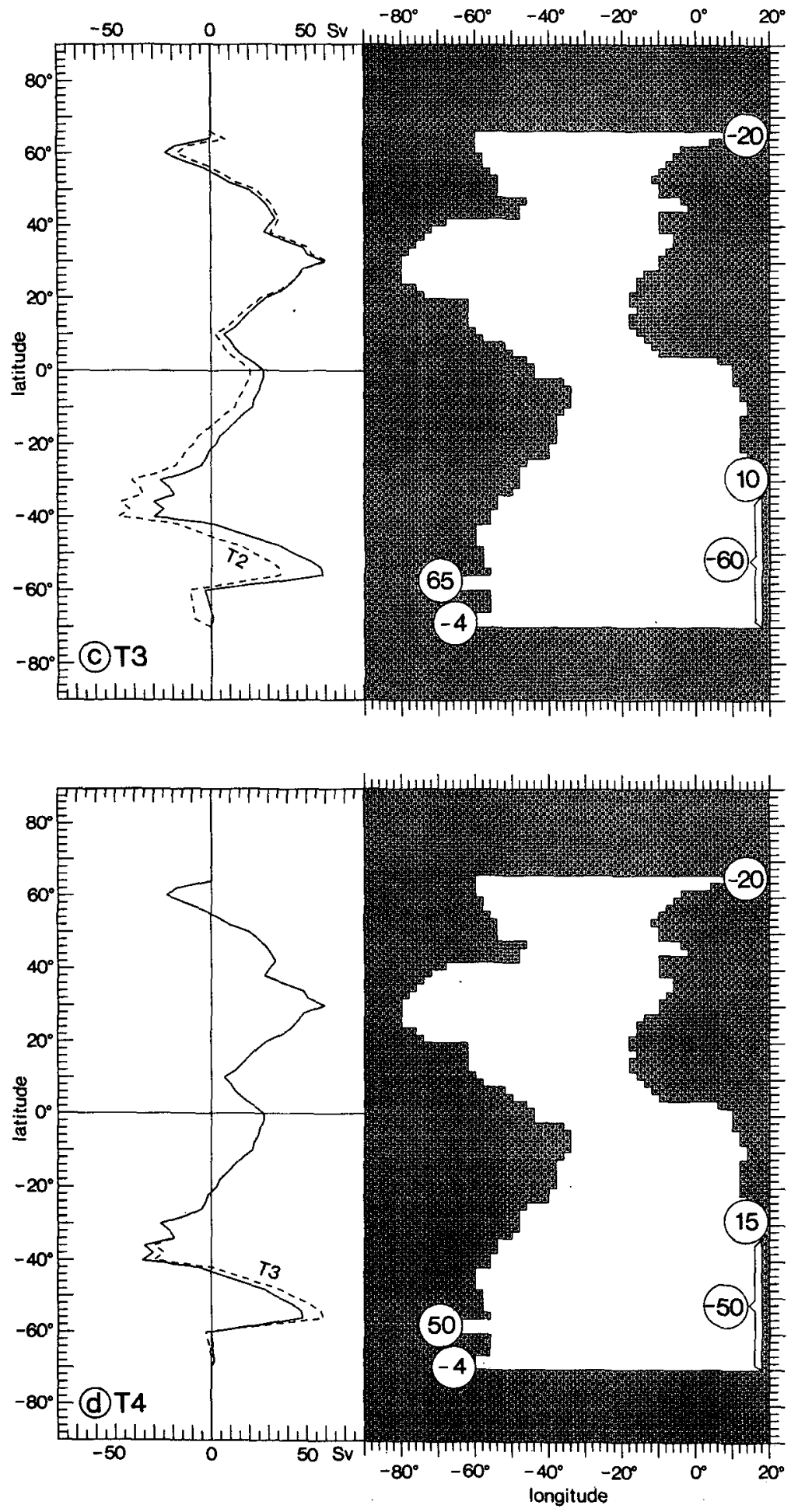

FIG. 8. (c) T3: the "cold water route": return flow via the Drake Passage, and (d) T4: the "warm water route": return flow via the Agulhas Current. Right panel: distribution and strength (in Sv) of concentrated sources and sinks (approximate locations). Negative numbers refer to sinks (downwelling); sources are indicated by positive values (upwelling). Left panel: the corresponding western boundary current transports, $T_{W}$. Transport patterns from preceding runs have been added as dashed lines and are labeled by denotation of that run. 
observed WBC asymmetries at least to first order. To illustrate this, the WBC transport of run T4 (Fig. 8d) and the transport numbers gained from observations (Fig. 1) have been combined in Fig. 9. The surprising result is that the major observed asymmetries are reproduced by the model qualitatively and quantitatively to a high degree, but there are also dissimilarities.

For the subtropical WBCs, the model yields peak transports of $59.4 \mathrm{~Sv}$ for the FC and $-34.8 \mathrm{~Sv}(-29.8$ $\mathrm{Sv}$ in T3) for the BC. The corresponding extreme values from observations are 64 and $-23 \mathrm{~Sv}$, respectively. Hence, in the Northern Hemisphere, the model value lies below the observed value, in the Southern Hemisphere the model peak transport exceeds the observed. A possible cause for this asymmetric behavior might be that the thermohaline return flow in the model is too weak. In an additional run, it has been verified that $-25 \mathrm{~Sv}$ sinking in the North Atlantic and an enhanced return flow from other oceans of $20 \mathrm{~Sv}$ via the cold water route raises the FC peak transport to about 64.4 $\mathrm{Sv}$ and slows down the $\mathrm{BC}$ to $-24.8 \mathrm{~Sv}$, which is for both WBCs closer to the observations. In the light of recent direct measurements of the southward flowing North Atlantic Deep Water yielding transports of up to $35 \mathrm{~Sv}$ (Lee et al. 1990; Leaman and Harris 1990), such high overturning rates do not seem to be unrealistic.

For the NASBC, there are some differences between the model results and the observations worth discussion. In T3 and T4 the transport increases from 29.2 $\mathrm{Sv}$ at $20^{\circ} \mathrm{N}$ to its peak value at $30^{\circ} \mathrm{N}$. The observed values, however, are systematically lower in this latitude range and also the increase of transport with latitude is less than in the model. North of $30^{\circ} \mathrm{N}$, the observed transport suddenly increases, exceeds the modeled transport, and reaches its maximum value somedegrees farther north. A reason for this discrepancy is probably the neglect of that part of the WBC that is located on the eastern flank of the West Indies and the Bahamas, that is, the Antilles Current. If such a current really exists as an independent branch of the WBC (and this is not yet clear, cf. Gunn and Watts 1982; Olson et al. 1984; Lee et al. 1990), then the branching might occur at about the latitude of Puerto Rico $\left(\sim 18^{\circ} \mathrm{N}\right)$ and the current would merge again with the FC to the north of the Bahamas island arc somewhere around $30^{\circ} \mathrm{N}$ (cf. Sverdrup et al. 1942, Figs. 174, 187). Between $13^{\circ} \mathrm{N}$ and $30^{\circ} \mathrm{N}$ the transport contribution of this current is not contained in the observational data, which are confined to the integrated inflow through the passages of the Lesser Antilles and the WBC branch between the Bahamas and Florida, that is, the FC. That makes the observed transport numbers and the latitudinal increase smaller than the modeled transport, which does not distinguish between the two branches of the WBC. The excess observed transport north of $\sim 30^{\circ} \mathrm{N}$ is possibly caused by a Gulf Stream recirculation pattern (Schmitz 1980) driven by nonlinear po-

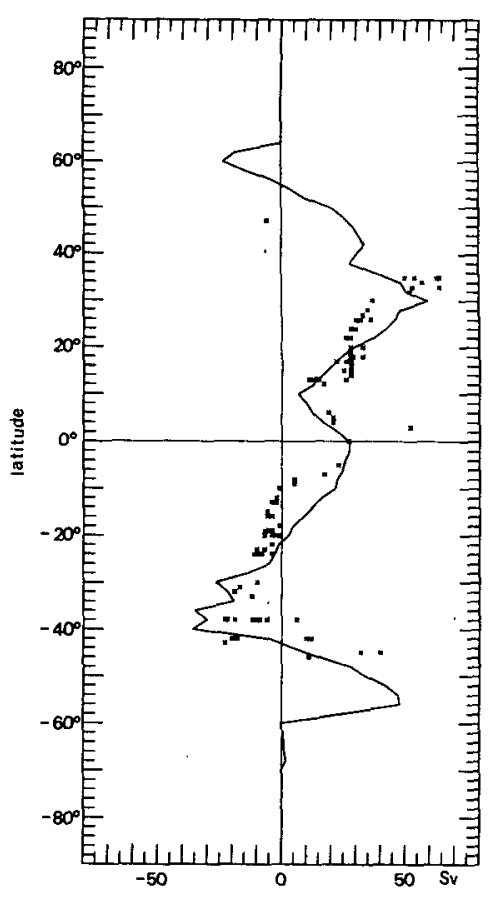

FIG . 9. Comparison of observed (asterisks, cf. Fig. 1) and modeled (continuous line, cf. Fig. 8d) WBC transports according to model run $\mathrm{T} 4$.

tential vorticity fluxes, which cannot be reproduced by the model.

Also in the BC area there is a systematic difference between observed and modeled transports. The model suggests a BC limited to the latitude range between $21^{\circ} \mathrm{S}$ and $41^{\circ} \mathrm{S}$. The observations, however, give clear evidence for the southward flow regime to begin already at $10^{\circ} \mathrm{S}$. A possible explanation for this difference is that except for the observations of Evans et al. (1983, cf. Table 1) all observed numbers refer to transports above 500 or $600 \mathrm{~m}$ excluding any contribution from the northward flowing Antarctic Intermediate Water (AAIW), the transport of which is part of the thermohaline return flow. Hence, the difference suggests that the northward AAIW transport may reach up to $20 \mathrm{~Sv}$ at $10^{\circ} \mathrm{S}$. In light of Fu's (1981) results, such a high number does not seem to be unrealistic.

Observations demand a northward equator-crossing NBC flow beginning at $\sim 10^{\circ} \mathrm{S}$, the transport of which increases rapidly when approaching the equator. To the north of the equator, the transport decreases and a minimum seems to occur in the vicinity of $10^{\circ} \mathrm{N}$, but the position of this minimum is rather unclear because of lack of data. After that, an increase of transport due to the NASBC can be found. This WBC pattern is remarkably well reproduced by the model. Due to the inclusion of the AAIW discussed above, the beginning of the NBC is shifted farther south, but at $5^{\circ} \mathrm{S}$ the transport is already very close to observations and at the equator the WBC curve exactly meets the observed 
transport of $27.4 \mathrm{~Sv}$. According to Table 1, this good agreement is probably due to the deeper reference level of $1000 \mathrm{~m}$ including the AAIW. After having crossed the equator, the WBC transport decreases to a wellpronounced minimum of $6.7 \mathrm{~Sv}$ at $10^{\circ} \mathrm{N}$ and increases again to the north of this latitude.

The largest differences between observed and modeled transports can be found in the subpolar WBCs. For the LC, the model diagnoses southward transport between $55^{\circ} \mathrm{N}$ and $63^{\circ} \mathrm{N}$ exhibiting a maximum of 23 Sv at $60^{\circ} \mathrm{N}$. Observations, however, suggest southward transport of only $6 \mathrm{~Sv}$ at $47^{\circ} \mathrm{N}$-about $8^{\circ}$ farther south of the latitude belt, where the model results yield a southward WBC. Hence, the transport numbers and the direction of the flow are wrong in the model in this latitude range. In the other hemisphere there seems to be some better agreement between modeled and observed subpolar WBC transports. Maximum observed $\mathrm{MC}$ transports of $40 \mathrm{~Sv}$ can be found at $45^{\circ} \mathrm{S}$; the model suggests a transport maximum of $58.7 \mathrm{~Sv}$ (T3) or 47.8 $\mathrm{Sv}$ (T4) at $54^{\circ} \mathrm{S}$. Thus, at least the maximum transports are of about the same magnitude. Although the variance of observed transports is very large in the $\mathrm{BC} /$ $\mathrm{MC}$ confluence region, the data suggest the model MC to be located too far south. This is another indication that the assumed thermohaline return flow could be too weak. Recalling the results of the run with enhanced overturning (see above), the $\mathrm{BC}-\mathrm{MC}$ confluence is shifted by about $5^{\circ}$ toward the equator.

\section{Discussion}

It has been shown that the major asymmetries of WBCs about the equator are reproduced by the model. The results are giving answers to the original questions, as to what extent these asymmetries might be caused either by interhemispheric asymmetries of the wind stress pattern, the shape of coastal boundaries, or the thermohaline circulation. Regarding the first two questions, the results can be summarized as follows:

- Asymmetries of observed climatological wind stress pattern cause only asymmetries of the tropical equatorward boundary currents North Tropical Current and South Tropical Current.

- Using realistic coast lines (W4) reduces all WBC transports, but further asymmetries do not arise and the asymmetries of the tropical WBCs are preserved.

- Substitution of the zonally averaged wind stress pattern by climatological stresses varying along a latitude circle and containing also nonzero meridional components (W5) makes the amplitudes of North Tropical Current and South Tropical Current nearly equal.

Hence, there is no indication that WBC asymmetries are caused by the shape of the coastlines. It is only possible to attribute about $12 \mathrm{~Sv}$ of the cross-equatorial WBC to nonzero wind stress curl along the equator.
Addition of a thermohaline flow component has some striking effects on the WBC structure.

- The simple assumption of $20 \mathrm{~Sv}$ sinking in the northern North Atlantic, compensated by uniform upwelling over the entire Atlantic basin ( $T 1$ ), reproduces all observed asymmetries qualitatively. Addition of another $4 \mathrm{~Sv}$ of sinking in the Weddell Sea does not alter the result significantly.

- Definition of a $15 \mathrm{~Sv}$ thermohaline return flow via the "cold" or "warm water route" reinforces the asymmetries and makes them also quantitatively comparable with observations.

Hence, all known WBC asymmetries can be explained by making only a few assumptions on the sink/source distribution of the thermohaline flow pattern. One should keep in mind that this is only true for WBCs as long as they are confined to the coast. It cannot be expected that any reliable transport estimates can be derived from a linear model for WBCs after they have left the western boundary, because the enormous increase of transport rates in these regions can only be explained by nonlinear eddy-mean flow interaction leading to countercurrents and recirculation gyres (Hogg et al. 1986; Schmitz 1980; Holland et al. 1983).

Additionally, the following conclusions concerning some actual problems of the large-scale circulation and interocean exchange of mass and heat can be drawn from model runs $\mathrm{T} 3$, T4.

- The total cross-equatorial transport via the NBC can be separated into a wind-driven part of about 12 $\mathrm{Sv}$ and a thermohaline part of about $15 \mathrm{~Sv}$. Only the latter contributes to the northward heat transport because the wind-driven part is compensated by a southward cross-equatorial flow of water at about the same temperature to the east of the western boundary layer.

- The strong decrease of the WBC from 27.4 Sv to $6.7 \mathrm{~Sv}$ between the equator and $10^{\circ} \mathrm{N}$ implies that about $20 \mathrm{~Sv}$ of South Atlantic water is fed into the Equatorial Undercurrent and the North Equatorial Countercurrent and leaves only the minor part to proceed along the Brazilian coast directly to the Caribbean Sea, an amount close to that found by Schott and Böning (1991) using a primitive equation model. This implies that the major route for the interocean heat exchange occurs northwestward via the NBC, eastward via the Equatorial Undercurrent/North Equatorial Countercurrent, and then again to the west via the North Equatorial Current into the western Atlantic.

- The WBC minimum at $10^{\circ} \mathrm{N}$ can be explained as being the remnants of a cyclonic wind-driven tropical gyre, the WBC of which had to change its flow direction because of the superimposed thermohaline flow.

- At $26^{\circ} \mathrm{N}$ the model diagnoses a WBC transport of 45.8 Sv from which $25.7 \mathrm{~Sv}$ or $56 \%$ are wind driven (W5). According to observations (Niiler and Richardson 1973), the FC transport is $29.5 \mathrm{~Sv}$ at this latitude, 
leaving up to $16 \mathrm{~Sv}$ for a potential Antilles Current. Assuming the same ratio between the wind-driven and thermohaline part of the flow in both currents, suggests that about $12.9 \mathrm{~Sv}$ is due to thermohaline and $16.6 \mathrm{~Sv}$ is due to wind-driven transport for the FC at that latitude-approximately the same ratio has been found by Schmitz and Richardson (1991) from water mass analysis and approximately the same as in Roemmich and Wunsch (1985, Table 2) [also adapted and reinterpreted by Schmitz et al. (1992), Table 1], who attributed $23 \mathrm{~Sv}$ of a total WBC flow of $40 \mathrm{~Sv}$ to wind forcing at $24^{\circ} \mathrm{N}$.

The comparison of model results with observations has shown remarkably good agreement in tropical and subtropical latitudes; however, in subpolar latitudes the model fails. This is probably due to the general concept of separating the ocean into an upper layer, driven by wind and thermohaline forcing, and a purely thermohaline-driven lower layer, which is not appropriate for describing the large-scale circulation in high latitudes-especially in the Northern Hemisphere, where deep winter convection plays a dominant role. Due to such convection events and the lack of stratification the wind-generated turbulent friction does not disappear at some intermediate depth but reaches much farther down in the interior of the subpolar gyre.

This model was intended to describe observed asymmetries of WBCs in the upper Atlantic Ocean. It has not yet been clarified, what "upper ocean" means, but it becomes clear in the light of the model results. The upper ocean includes that part of the water column where the thermohaline return flow compensating for the southward flow of North Atlantic Deep Water occurs; in tropical and subtropical latitudes that is the main thermocline and the AAIW. In reality, this water volume is meridionally limited by the polar fronts, and the vertical boundary varies regionally between about $1000-\mathrm{m}$ and $1500-\mathrm{m}$ depth in the interior. In the model, however, the lower boundary is not specified in terms of a variable depth but is defined to be flat extending over the entire Atlantic. In addition, it is postulated that all wind-driven flow occurs in that layer. This is a strong simplification, but the model results suggest that this concept is correct to first order in tropical and subtropical latitudes.

Several additional simplifying assumptions have been made, and how much these might contaminate the model results has to be discussed. Sinking at high latitudes occurs in a $2^{\circ} \times 2^{\circ}$ grid cell. This is surely not correct, but if the sinking is spread out over a larger area, it will affect the model results only slightly in that latitude belt and the WBCs south of that area will be unchanged. In the same way it can be ruled out that to the north of the latitude of Cape Agulhas the model results are sensitive to the definition of the $\mathrm{CC} / \mathrm{AgC}$, as long as the flow between Africa and Antarctica compensates for the flow through Drake Passage. This is the case in runs $\mathrm{W} 1$ to $\mathrm{W} 5$ and in $\mathrm{T} 1, \mathrm{~T} 2$. In $\mathrm{T} 3$ and T4, however, an imbalance between the transports through these passages has been specified in order to model the return flow from other oceans. The existence of a return flow is still in the stage of a theory, and one must admit that nowadays its magnitude is not well known. On the other hand, at least $13 \mathrm{~Sv}$ net input (15 Sv return flow, $-4 \mathrm{~Sv}$ sinking in the Weddell Sea and $\sim 2 \mathrm{~Sv}$ upwelling) into the Southern Ocean is needed in order to explain the observed WBC asymmetries. Another question is to what extent the uniform upwelling is a good approach for what really happens in the ocean? This question is only relevant for the Atlantic Ocean because the return flow from other oceans is defined by concentrated sources in the passages and it is irrelevant by which process this water has been transformed from deep water to upper-layer water. In the Atlantic, however, only $9 \mathrm{~Sv}$ are left for uniform upwelling. If one takes into account that a certain amount is needed everywhere for keeping the shape of the thermocline, it is for the model results of secondorder importance where the rest upwells.

As mentioned earlier, the idea of superimposing a thermohaline component on the wind-driven flow in the upper ocean can be traced back to Stommel (1957). The governing linear $\beta$-plane equations have been presented by Stommel (1965). Based on this concept and inspired by observations, Stommel (1957, Fig. 10; 1965, Fig. 82) shows charts of transports both in the lower and upper layer of the Atlantic Ocean, from which upper-layer WBC transports can be deduced, that are remarkably similar to those presented in model runs $\mathrm{T} 3$ and $\mathrm{T} 4$. The important difference between the present investigation and Stommel's studies is that his charts are only schematic. They have been constructed by simply adding a thermohaline WBC to the WBC transport given by Munk's solution for the wind-driven transport. The magnitude of the thermohaline WBC was about $20 \mathrm{~Sv}$ in the South and tropical North Atlantic and $30 \mathrm{~Sv}$ in the northern North Atlantic; thus Stommel did not account for the gradual WBC transport change inferred from upwelling in the ocean interior. In the present study, however, transport numbers for the WBCs are provided in $2^{\circ}$ intervals in a realistically bounded double-hemispheric ocean. They are based on generally accepted climatological wind stress fields, actual estimates of deep water production at high latitudes, and recently developed thermohaline return flow concepts.

\section{Conclusions}

A linear model has been presented for the upper Atlantic Ocean, shedding more light on the causes for observed asymmetries of western boundary currents. The following conclusions can be directly drawn from the model results or from comparing the results with observations: 
- The observed asymmetries cannot be caused by the shape of the coastlines.

- Asymmetries of the wind stress contributes to about $12 \mathrm{~Sv}$ wind-driven cross-equatorial flow in the North Brazil Current. The rest is thermohaline driven.

- All other asymmetries can be explained qualitatively and most of them quantitatively by the superimposed thermohaline flow requiring about two-thirds of thermohaline return flow from other oceans via the Agulhas Current and/or through the Drake Passage.

- Only the minor part of thermohaline return flow takes the shortest route from the equator to the Caribbean; the major part is taking the detour via the North Equatorial Countercurrent-North Equatorial Current.

- At $26^{\circ} \mathrm{N}$, about $56 \%$ of the western boundary current transport is wind driven.

- There is further indication for the existence of an Antilles Current carrying about $16 \mathrm{~Sv}$ to the north.

- There is indication for about $20 \mathrm{~Sv}$ northward transport of Antarctic Intermediate Water at $10^{\circ} \mathrm{S}$.

- The model yields poor results for subpolar latitudes.

Acknowledgments. I would like to thank two anonymous reviewers for excellent and encouraging comments. This work is a contribution to Grant 03F005D of the German Bundesministerium für Forschung und Technologie.

\section{APPENDIX A}

\section{Abbreviations}

$\begin{array}{ll}\text { AgC } & \text { Agulhas Current } \\ \text { BC } & \text { Brazil Current } \\ \text { CC } & \text { Circumpolar Current } \\ \text { FC } & \text { Florida Current } \\ \text { LC } & \text { Labrador Current } \\ \text { MC } & \text { Malvinas Current } \\ \text { NASBC } & \text { North Atlantic subtropical boundary current } \\ \text { NBC } & \text { North Brazil Current } \\ \text { WBC } & \text { Western boundary current }\end{array}$

\section{REFERENCES}

Barrett, J. R., 1965: Subsurface currents off Cape Hatteras. DeepSea Res., 12, 173-184.

Broecker, W. S., 1991: The great ocean conveyor. Oceanography, 4(2), 79-89.

Bryan, K., and M. D. Cox, 1972: The circulation of the world ocean: A numerical study. Part I: A homogenous model. J. Phys. Oceanogr., 2, 319-335.

—, S. Manabe, and R. C. Pacanowski, 1975: A global ocean-atmosphere climate model. Part II: The oceanic circulation. $J$. Phys. Oceanogr., 5, 30-46.

Bye, J. A. T., and T. W. Sag, 1972: A numerical model for circulation in a homogenous world ocean. J. Phys. Oceanogr., 2, 305-318.
Clarke, R. A., 1984: Transport through the Cape Farewell-Flemish Cap section. Rapp. P. V. Reun. Cons. Int. Explor. Mer, 185, $120-130$.

Evans, D. L., and S. G. Signorini, 1985: Vertical structure of the Brazil Current. Nature, 315, 48-50.

,-- , and L. B. Miranda, 1983: A note on the transport of the Brazil Current. J. Phys. Oceanogr., 13, 1732-1738.

Febres-Ortega, G., and L. E. Herrera, 1976: Caribbean Sea circulation and water mass transports near the Lesser Antilles. Bol. Inst. Oceanogr. Univ. Oriente, 15, 83-96.

Flagg, C. N., R. L. Gordon, and S. McDowell, 1986: Hydrographic and current observations on the continental slope and shelf of the western equatorial Atlantic. J. Phys. Oceanogr., 16, 14121429.

Fu, L.-L., 1981: The general circulation and meridional heat transport of the subtropical South Atlantic determined by inverse methods. J. Phys. Oceanogr., 11, 1171-1193.

Garner, D. M., 1962: The average horizontal wind-driven mass transport of the Atlantic for February as obtained by numerical methods. Proc. Symp. on Mathematical-Hydrodynamical Methods of Physical Oceanography, Hamburg, Institut für Meereskunde an der Universität Hamburg, 297-327.

Garzoli, S. L., and A. Bianchi, 1987: Time-space variability of the local dynamics of the Malvinas-Brazil confluence as revealed by inverted echo sounders. J. Geophys. Res., 92(C2), 19141922.

- , and Z. Garaffo, 1989: Transport, frontal motions and eddies at the Brazil-Malvinas Currents confluence. Deep-Sea Res., 36, 681-703.

Godfrey, J. S., 1989: A Sverdrup model of the depth-integrated flow for the world ocean allowing for island calculations. Geophys. Astrophys. Fluid Dyn., 45, 89-112.

Gordon, A. L., 1967: Circulation of the Caribbean Sea. J. Geophys. Res., 72, 6207-6223.

- 1986: Interocean exchange of thermocline water. J. Geophys. Res., 91(C4), 5037-5046.

_- 1989: Brazil-Malvinas confluence-1984. Deep-Sea Res., 36, 359-384

- and C. L. Greengrove, 1986: Geostrophic circulation of the Brazil-Malvinas confluence. Deep-Sea Res., 33, 573-585.

Gunn, J. T., and D. R. Watts, 1982: On the currents and water masses north of the Antilles/Bahamas arc. J. Mar. Res., 40, 118.

Han, Y.-J., 1984a: A numerical world ocean circulation model. Part I: Basic design and barotropic experiment. Dyn. Atmos. Oceans, $8,107-140$.

- , 1984b: A numerical world ocean circulation model. Part II: A baroclinic experiment. Dyn. Atmos. Oceans, 8, 141-172.

Hazelworth, J. B., and R. B. Starr, 1975: Oceanographic conditions in the Caribbean Sea during the summer of 1971. Tech. Rep. ERL-344-AOML20, NOAA, Washington, D.C., 144 pp.

Hellerman, S., and M. Rosenstein, 1983: Normal monthly wind stress of the World Ocean with error estimates. J. Phys. Oceanogr., 13, 1093-1104.

Hill, H. W., P. G. W. Jones, J. W. Ramster, and A. R. Folkard, 1972: The current system east of Newfoundland Grand Bank. ICNAF Special Publ. No. 10, 41-55.

Hogg, N. G., R. S. Pickard, R. M. Hendry, and W. J. Smethie, Jr., 1986: The northern recirculation gyre of the Gulf Stream. DeepSea Res., 33, 1139-1165.

Holland, W. R., D. E. Harrison, and A. Semtner, 1983: Eddy-resolving numerical models of large-scale ocean circulation. Eddies in Marine Science, A. R. Robinson, Ed., Springer-Verlag, 389403.

Johannessen, O. M., 1968: Preliminary results of some oceanographical observations carried out between Barbados and Tobago, March/April, 1968. Mar. Sci. Manuscript Rep. 8, McGill University, Montreal, Quebec, $14 \mathrm{pp}$.

Joyce, T. M., 1988: On the wind-driven cross-equatorial flow in the Atlantic Ocean. J. Phys. Oceanogr., 18, 793-799. 
Killworth, P. D., 1983: Deep convection in the World Ocean. Rev. Geophys. Space Phys., 21 (1), 1-26.

Knauss, J. A., 1969: A note on the transport of the Gulf Stream. Deep-Sea Res., 16, 117-123.

Leaman, K. D., and J. E. Harris, 1990: On the average absolute transport of the deep western boundary currents east of Abaco Island, the Bahamas. J. Phys. Oceanogr., 20, 467-475.

Lee, T. N., W. Johns, F. Schott, and R. Zantopp, 1990: Western boundary current structure and variability east of Abaco, Bahamas at $26.5^{\circ}$ N. J. Phys. Oceanogr., 20, 446-466.

Mazeika, P. A., 1973: Circulation and water masses east of the Lesser Antilles. Dtsch. Hydrogr. Z., 26, 49-73.

—_ D. A. Burns, and T. H. Kinder, 1980: Mesoscale circulation east of the Lesser Antilles. J. Geophys. Res., 85(C5), 27432758.

McCartney, M. S., and L. D. Talley, 1984: Warm-to-cold water conversion in the northern North Atlantic. J. Phys. Oceanogr., 14, 922-935.

Mellor, G. L., C. R. Mechoso, and E. Keto, 1982: A diagnostic calculation of the general circulation of the Atlantic Ocean. DeepSea Res., 29(10A), 1171-1192.

Miranda, L. B., and B. M. Castro Filho, 1982: Geostrophic flow conditions of the Brazil Current at $19^{\circ}$ S. Ciencia Interamericana, 22, 44-48.

Model, F., 1950: Pillsburys Strommessungen und der Wasserhaushalt des Amerikanischen Mittelmeeres. Dtsch. Hydrogr. Z., 3, 5761 .

Montgomery, R. B., 1941: Transport of the Florida Current off Habana. J. Mar. Res., 4, 198-220.

Neumann, G., 1968: The general circulation of the oceans, Chapter V. Ocean Currents, G. Neumann, Ed., Elsevier.

Niiler, P. P., and W. S. Richardson, 1973: Seasonal variability of the Florida Current. J. Mar. Res., 31, 144-167.

Olson, D. B., F. A. Schott, R. J. Zantopp, and K. D. Leaman, 1984: The circulation east of the Bahamas as determined from a recent measurement program and historical XBT data. J. Phys. Oceanogr., 14, 1470-1487.

Peterson, R. G., and L. Stramma, 1991: Upper-level circulation in the South Atlantic Ocean. Progress in Oceanography, Vol. 26, Pergamon, 1-73.

Piola, A. R., and A. A. Bianchi, 1990: Geostrophic mass transports at the Brazil/Malvinas confluence. Trans. Amer. Geophys. Union (Eos), 71, $542 \mathrm{pp}$.

Richardson, P. L., and J. A. Knauss, 1971: Gulf Stream and western boundary undercurrent observations at Cape Hatteras. DeepSea Res., 18, 1089-1109.

Richardson, W. S., and W. J. Schmitz, Jr., 1965: A technique for the direct measurement of transport with application to the Straits of Florida. J. Mar. Res., 23, 172-185.

- - - and P. P. Niiler, 1969: The velocity structure of the Florida Current from the Straits of Florida to Cape Fear. DeepSea Res., 16(Suppl.), 225-231.

Rintoul, S. R., 1991: South Atlantic interbasin exchange. J. Geophys. Res., 96(C2), 2675-2692.

Roemmich, D., and C. Wunsch, 1985: Two transatlantic sections: Meridional circulation and heat flux in the subtropical North Atlantic Ocean. Deep-Sea Res., 32, 619-664.

Schemaninda, R., 1980: Ergebnisse ozeanologischer Untersuchungen mit dem FFS “Ernst Haeckel” im Konvergenzgebiet von Brasil- und Falklandstrom im Juni/Juli 1978. Beitr. Meereskunde, 44/ 45, 109-121.

Schmitz, W. J., Jr., 1980: Weakly depth-dependent segments of the North Atlantic circulation. J. Mar. Res., 38, 111-133.

- and P. L. Richardson, 1991: On the sources of the Florida Current. Deep-Sea Res., 38(Suppl.), 379-409.

- J. D. Thompson, and J. R. Luyten, 1992: The Sverdrup circulation for the Atlantic along $24^{\circ} \mathrm{N}$. J. Geophys. Res., 97(C5), $7251-7256$

Schott, F. A., and C. W. Böning, 1991: The WOCE model in the western equatorial Atlantic: Upper layer circulation. J. Geophys. Res., 96(C4), 6993-7004.

Semtner, A. J., and R. M. Chervin, 1988: A simulation of the global ocean circulation with resolved eddies. J. Geophys. Res., 93(C12), 15 502-15 522.

- , and - 1992: Ocean general circulation from a global eddyresolving model. J. Geophys. Res., 97(C4), 5493-5550.

Signorini, S. R., 1978: On the circulation and the volume transport of the Brazil Current between the Cape of São Tomé and Guanabara Bay. Deep-Sea Res., 25, 481-490.

Stalcup, M. C., and W. G. Metcalf, 1972: Current measurements in the passages of the Lesser Antilles. J. Geophys. Res., 77, 10321049.

Stommel, H., 1957: A survey of ocean current theory. Deep-Sea Res., 4, 149-184.

—, 1965: The Gulf Stream. University of California Press, $248 \mathrm{pp}$. , and A. B. Arons, 1960: On the abyssal circulation of the world ocean-I. Stationary flow patterns on a sphere. Deep-Sea Res., 6, 140-154.

Stramma, L., 1989: The Brazil Current transport south of $23^{\circ} \mathrm{S}$. DeepSea Res., 36, 639-646.

_- Y. Ikeda, and R. G. Peterson, 1990: Geostrophic transport in the Brazil Current region north of $20^{\circ} \mathrm{S}$. Deep-Sea Res., 37, $1875-1886$.

Sverdrup, H. U., M. W. Johnson, and R. H. Fleming, 1942: The Oceans. Their Physics, Chemistry and General Biology. PrenticeHall, $1087 \mathrm{pp}$

Swallow, J. C., and L. V. Worthington, 1961: An observation of a deep countercurrent in the western North Atlantic. Deep-Sea Res., 8, 1-19.

Veronis, G., 1973: Model of world ocean circulation: I. Wind-driven, two-layer. J. Mar. Res., 31, 229-289.

- 1981 : Dynamics of large-scale ocean circulation. Evolution of Physical Oceanography B. A. Warren and C. Wunsch, Eds., The MIT Press, 158-163.

Welander, $\mathrm{P} ., 1959:$ On the vertically integrated mass transport in the oceans. The Atmosphere and the Sea in Motion, B. Bolin, Ed., Oxford University Press, 95-101.

Wolford, T. C., 1966: Oceanography of the Grand Banks region and the Labrador Sea in 1966. Oceanography Report No. 13, U.S. Coast Guard, 176 pp.

Worthington, L. V., 1970: The Norwegian Sea as a Mediterranean basin. Deep-Sea Res., 17, 77-84.

Zemba, J. C., 1990: The Brazil Current at $31^{\circ} \mathrm{S}$ : Another look at its velocity structure and transport. Eos, Trans. Amer. Geophys. Union, 71, 544.

Zyryanov, V. N., and D. N. Severov, 1979: Water circulation in the Falkland-Patagonia region and its seasonal variation. Oceanology, 19, 518-522. 